\title{
INCREASING DIVERSITY IN THE SPECIES-RICH GENUS GUATTERIA (ANNONACEAE)
}

\author{
ROY H.J. ERKENS ${ }^{*}$, LUBBERT Y.TH. WESTRA ${ }^{2} \&$ PAUL J.M. MAAS ${ }^{2}$
}

\begin{abstract}
SUMMARY
A large amount of unidentified material of the Neotropical genus Guatteria (Annonaceae) is lying on herbarium shelves around the world. Here twelve species are described in an attempt to reduce this amount of unidentified material. Next to this, previously unidentified material is now assigned to G. asplundiana, G. microcarpa, G. pastazae, and G. scalarinervia, four previously described but poorly known species, thus providing a clearer circumscription of these species. Furthermore, G. discolor and G. megalophylla appear to have a wider distribution than previously thought. Lastly, G. macrantha, a curious species only known from the type, is excluded from the genus and referred to Uvaria. With the description of twelve new species and the synonymizing of one, the total number of species in Guatteria adds up to over 300, thus rivalling Inga (Fabaceae) and Ocotea (Lauraceae) for the status of largest genus of Neotropical trees.
\end{abstract}

Key words: Annonaceae, Guatteria, Neotropics, Bolivia, Brazil, Colombia, Ecuador, Peru.

\section{INTRODUCTION}

Guatteria (Annonaceae) is a large genus of exclusively Neotropical trees, so far comprising c. 290 species (Erkens 2007). It occurs throughout the Neotropics (except Argentina and Paraguay), with the most northern species probably being G. anomala R.E.Fr. (Mexico) and G. blainii (Griseb.) Urb. (Cuba). The species occurring furthest down south (Brazil, Santa Catarina) are G. neglecta R.E.Fr. and G. dusenii R.E.Fr., both likely synonyms of G. australis A.St.-Hil. However, there is unidentified material from Rio Grande do Sul (the most southern state of Brazil) that probably belongs to G. australis as well (A. Lobão, pers. comm.). The highest species diversity can be found in the Amazon basin, with approximately half of all Guatteria species occurring there. The Brazilian coastal areas are also species-rich. Central America harbours some 30 species and the Caribbean Islands only three.

The oldest published species now included in Guatteria is G. ouregou, originally described by Aublet (1775) as Cananga ouregou. Nowadays, the generic name Guatteria Ruiz \& Pav. is conserved. In 1794, Guatteria was described by Ruiz López \& Pavón in their 'Prodromus Florae Peruvianae' (Ruiz López \& Pavón 1794), but without any

1) Utrecht University, Faculty of Science, Institute of Environmental Biology, Section Plant Ecology and Biodiversity, Sorbonnelaan 16, 3584 CA Utrecht, The Netherlands.

2) Nationaal Herbarium Nederland, Utrecht University branch, Heidelberglaan 2, 3584 CS Utrecht, The Netherlands.

* Author for correspondence e-mail: R.H.J.Erkens@uu.nl; tel.: 0031-30-2536845. 
species mentioned. They named the genus after Don Juan Bautista Guátteri, who "died a few months ago, in the bloom of his life". They state that because of his death "the Royal Botanical Gardens of Parma (Italy) now lacked a very distinguished Professor and a very honourable person". In 1798, four species were included (Guatteria glauca, G. hirsuta, G. ovalis (now Ruizodendron ovale), and G. pendula (now Cremastosperma pendulum; Ruiz López \& Pavón 1798)), without typification of the generic name (the typification method did not yet exist in those days). Hutchinson (1923) designated G. glauca as lectotype (for a further discussion about conservation and lectotypification of Guatteria see Van Setten \& Maas (1990).

Almost twenty years after Ruiz López \& Pavón's initial description, Dunal (1817) wrote a monograph of the family of Annonaceae in which he mentioned 20 Guatteria species. At present his Asian species are no longer considered to belong to the genus (as said, Guatteria is exclusively Neotropical). Dunal described them as such based on the superficially similar monocarps. A further six of Dunal's species have been synonymized into other American Annonaceae genera, leaving only G. guianensis (his illegitimate G. aberemoa), G. eriopoda, G. glauca, G. hirsuta, and G. ouregou (incl. G. podocarpa DC.) as true members of the genus. Other early contributions to the taxonomy of Guatteria were made by De Saint-Hilaire $(1824-1825 ; 5$ new species), Von Schlechtendahl (1834; 5 new species), Von Martius (1841; 20 new species), Triana \& Planchon (1862; 11 new species), Diels (1905, 1906, 1924a, b, 1927, 1931; 20 species), and Fries (1938; 12 new species). Because of these efforts, at the start of the revision work by Robert Fries (published in 1939 and the only revision to date), already 151 species of Guatteria had been described. Fries synonymized six of these and transferred 36 species to a different genus. As an addition he placed two species in Guatteria that had been described earlier in other genera of Annonaceae (G. axilliflora (DC.) R.E.Fr. was described as Annona axilliflora DC., and G. guianensis (Aubl.) R.E.Fr. as Aberemoa guianensis Aubl.). He himself then described 106 new species in his revision (Fries 1939). These additions made Guatteria, with 217 species, already one of the largest Annonaceae genera at that time. In order to create some order in the taxonomy of Guatteria Fries erected 30 sections (Table 1; Fries 1939). Later he recognised two subgenera: Anomalantha (containing only Guatteria anomala) and Guatteria (containing all other species in the genus; Fries 1955). Several years after that (Fries 1959b) he reduced the number of sections to 22, merging several not well circumscribed ones (Table 1).

Since Fries' 1939 treatment, the number of species has gradually increased, mainly because of work by Fries himself (Fries 1947, 1948a, b, 1950, 1952, 1956, 1957a, b, 1959a; Maguire et al. 1957, 1960; totalling 36 new species). Apart from several more described species, larger recent contributions were made by Maas et al. (1988; 4 new species), Scharf et al. (2005; 2006a, b; 12 new species), and Erkens et al. (2006; 5 new species). The total number of species currently recognised is 286 , and with the merging of three small, related genera with Guatteria (Erkens \& Maas 2008) reaches 294. The genus already rivals Inga (Fabaceae; c. 300 spp.) and Ocotea (Lauraceae; c. 300 spp.) for the status of largest genus of Neotropical trees. Yet many more new species are probably awaiting description because a large amount of unidentified material of Guatteria is lying on herbarium shelves around the world, c. 1500 specimens at the 
Table 1. Overview of sections in Guatteria described by Fries (1939) and revised later (Fries 1955; 1959). Monotypic sections Acrantha (G. terminalis) and Pycnantha (G. elongata) were described in 1939 but were not mentioned in subsequent publications. Therefore, whether Fries submerged or abolished these sections is not clear.

\begin{tabular}{|c|c|c|}
\hline $\begin{array}{l}\text { Fries } 1939 \\
\text { Section: }\end{array}$ & $\begin{array}{l}\text { Fries } 1955 \\
\text { Subgenus: }\end{array}$ & $\begin{array}{l}\text { Fries } 1959 \\
\text { Section (including): }\end{array}$ \\
\hline Anomalantha & Anomalantha & ----- \\
\hline Acrantha & Guatteria & $?$ \\
\hline Asterantha & Guatteria & ----- \\
\hline Austroguatteria & Guatteria & Austroguatteria (Asterantha, Microcalyx, Microphyllum) \\
\hline Brachystemon & Guatteria & Brachystemon \\
\hline Cephalocarpus & Guatteria & Cephalocarpus \\
\hline Chasmantha & Guatteria & Chasmantha \\
\hline Cordylocarpus & Guatteria & Cordylocarpus \\
\hline Dichrophyllum & Guatteria & Dichrophyllum \\
\hline Dimorphopetalum & Guatteria & Dimorphopetalum \\
\hline Dolichocarpus & Guatteria & Dolichocarpus \\
\hline Eu-Guatteria & Guatteria & Guatteria (Macrophyllum) \\
\hline Leiophyllum & Guatteria & Leiophyllum \\
\hline Leptophyllum & Guatteria & Leptophyllum \\
\hline Macroguatteria & Guatteria & Macroguatteria \\
\hline Macrophyllum & Guatteria & ----- \\
\hline Mecocarpus & Guatteria & Mecocarpus \\
\hline Megalophyllum & Guatteria & Megalophyllum \\
\hline Microcalyx & Guatteria & ----- \\
\hline Microphyllum & Guatteria & ----- \\
\hline Oligocarpus & Guatteria & Oligocarpus \\
\hline Pteropus & Guatteria & Pteropus \\
\hline Pycnantha & Guatteria & $?$ \\
\hline Sclerophyllum & Guatteria & Sclerophyllum \\
\hline Stenocarpus & Guatteria & Stenocarpus \\
\hline Stenophyllum & Guatteria & ----- \\
\hline Stigmatophyllum & Guatteria & Stigmatophyllum \\
\hline Trichoclonia & Guatteria & Trichoclonia (Stenophyllum) \\
\hline Trichostemon & Guatteria & Trichostemon \\
\hline Tylodiscus & Guatteria & Tylodiscus \\
\hline
\end{tabular}

Utrecht herbarium alone. The twelve species described here are a first step in an effort to reduce the amount of unidentified material. Furthermore, material so far undetermined is now assigned to four previously described but poorly known species, thus providing a clearer circumscription of these species. Also, two species have a wider distributional range than previously thought. Lastly, one species only known from the type is assigned to another genus. The total number of accepted names in Guatteria, including the new species described elsewhere in this issue (Scharf et al. 2008), therefore now adds up to 307 .

\section{MATERIAL AND METHODS}

Herbarium material was investigated from the following herbaria: CUVC, GOET, K, MAD, MO, NY, PR, U, and WIS. Measurements as a rule were made of dried material. Measurements of material in spirit are given between accolades \{\} . Colour indica- 


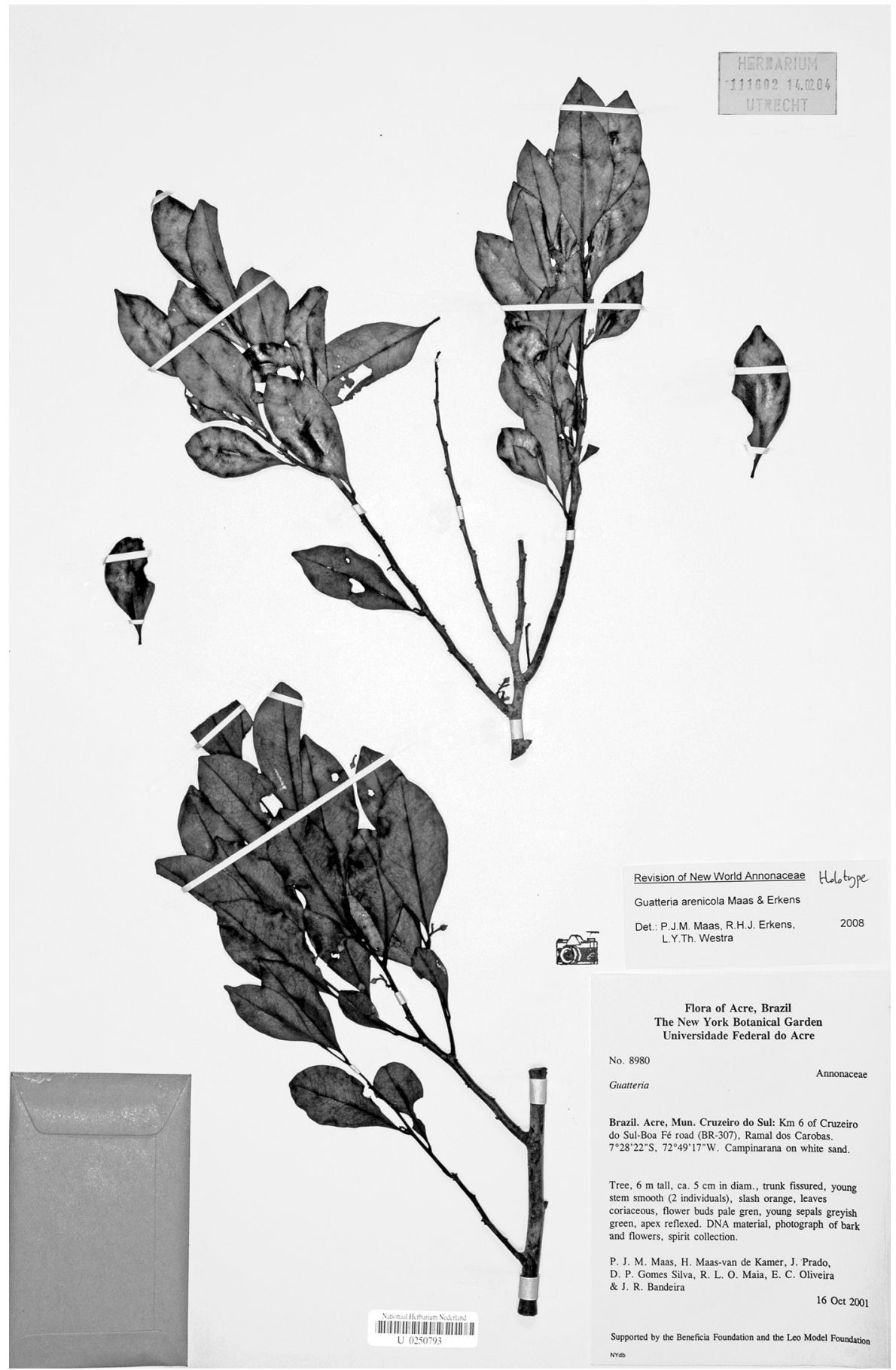

Fig. 1. Guatteria arenicola Maas \& Erkens. Flowering twig (Maas et al. 8980, holo U). 
tions and descriptions of surface structures are based on dried material, unless stated otherwise. We indicate the density of the indument by using the following gradations: densely, rather densely, and sparsely. Seed surface is indicated as foveolate (pitted) or rugose (wrinkled; looks like a miniature brain) according to Van Setten \& KoekNoorman (1992).

\section{DESCRIPTION OF SPECIES}

\section{Guatteria arenicola Maas \& Erkens, spec. nov. - Fig. 1; Plate 1; Map 1}

Frutex vel arbor parva, foliis pro genere parvis coriaceis basi attenuatis, pedicellis recurvatis distincta. - Typus: Maas et al. 8980 (holo U; iso NY), Brazil, Acre, km 6 of road from Cruzeiro do Sul to Boa Fé (BR-307), Ramal dos Carobas, c. 200 m, 16 October 2001.

Shrub or tree 2-30 m tall, 5-40 cm diam., trunk fissured, slash orange (in material from Acre); young twigs densely to sparsely covered with appressed hairs, soon glabrous. Leaves: petiole $2-5 \mathrm{~mm}$ long, $1 \mathrm{~mm}$ diam.; lamina elliptic to narrowly elliptic, 5-9 by $1-3 \mathrm{~cm}$ (leaf index 2-3.6), coriaceous to chartaceous, not verruculose, dull, dark brown, brownish black to greyish black above, somewhat paler brown below, glabrous, except for the hairy primary vein above, rather densely to sparsely covered with appressed hairs below, base attenuate to acute, apex shortly and bluntly acuminate (acumen 1-3 $\mathrm{mm}$ long) to rounded, primary vein slightly impressed to flat above, secondary veins indistinct to distinct, 6-13 on either side of primary vein, flat to prominent above, secondary and tertiary veins reticulate and prominent on both sides, smallest distance between loops and margin 2-3 mm. Flowers in leaf axils, solitary; pedicels strongly recurved (Acre) to erect, $10-13 \mathrm{~mm}$ long and $1 \mathrm{~mm}$ diam., fruiting pedicels $15-20 \mathrm{~mm}$

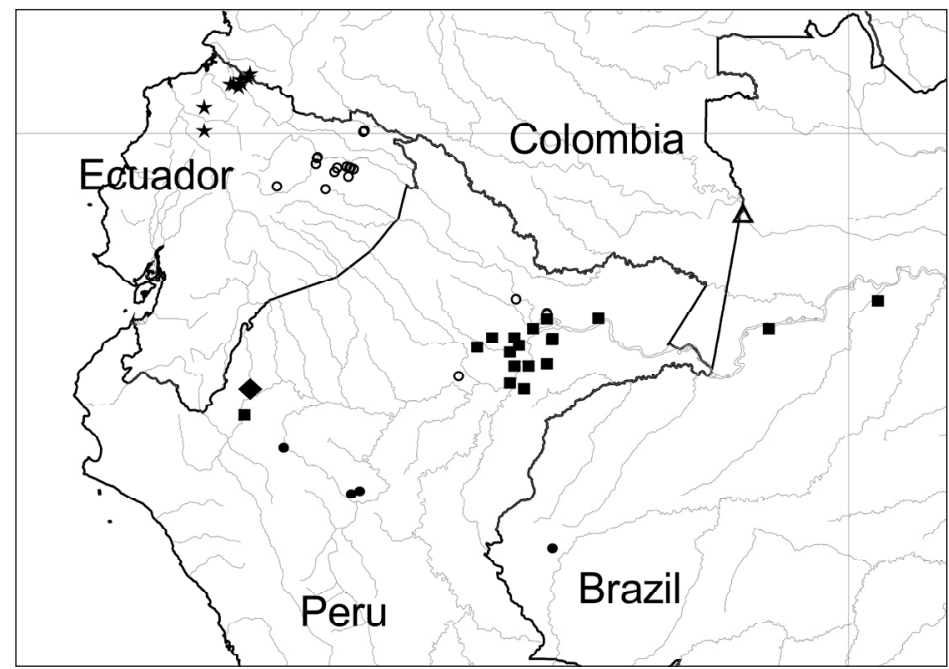

Map 1. Distribution of Guatteria arenicola Maas \& Erkens (•), G. flabellata Erkens \& Maas (๘), G. flagelliflora Maas \& Westra $(\checkmark)$, G. japurensis Maas \& Westra $(\triangle)$, G. scalarinervia D.R.Simpson $(\bigcirc)$, G. venosa Erkens \& Maas ( $\star$ ). 


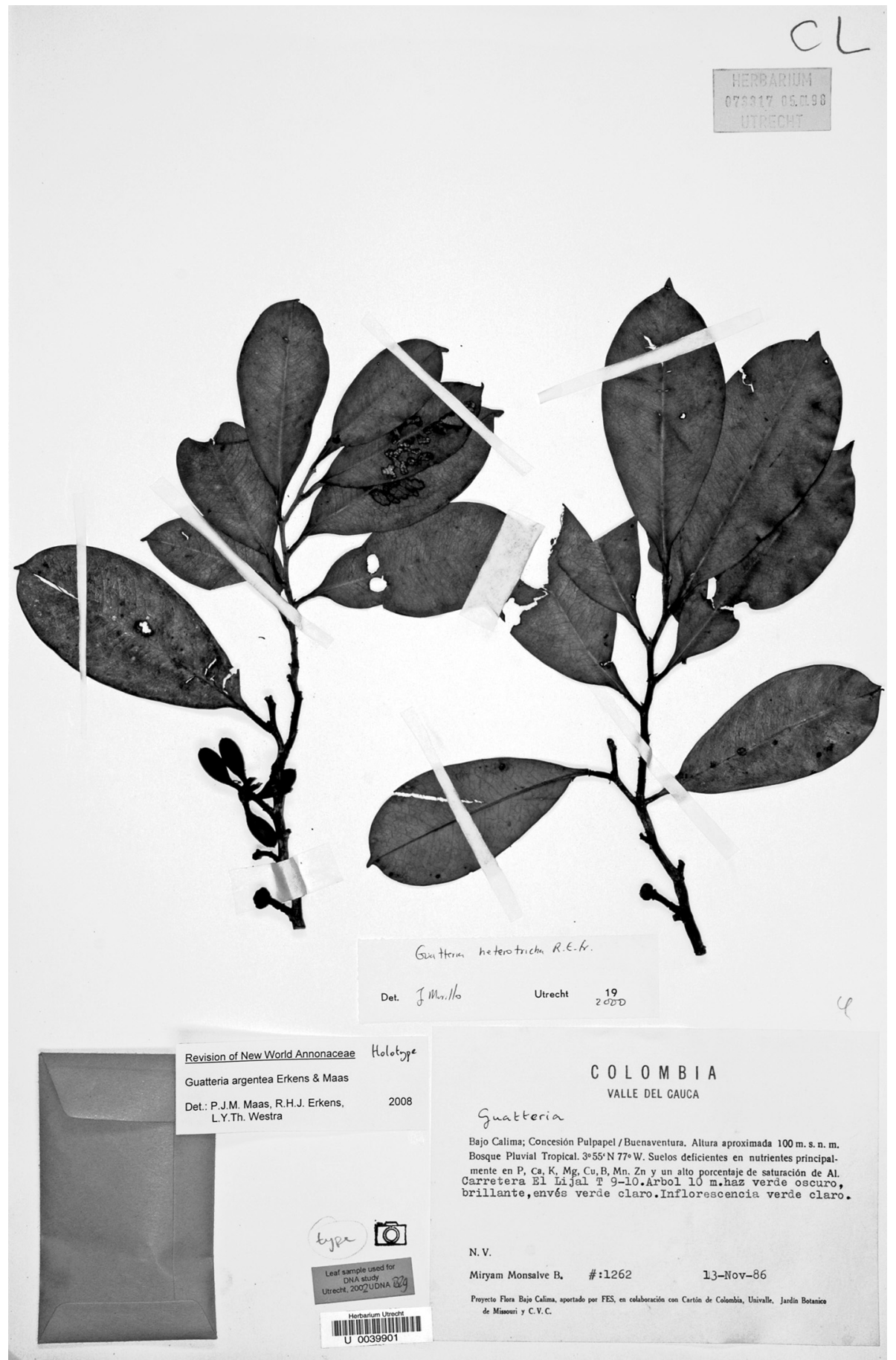

Fig. 2. Guatteria argentea Erkens \& Maas. Fruiting and sterile twig (Monsalve B. 1262, holo U). 
long and $2 \mathrm{~mm}$ diam., articulated at 1/5-1/2 from the base, bracts 4 or 5 below articulation, the 2 upper ones narrowly obovate, $4-6$ by $1.5-2 \mathrm{~mm}$, the 3 lower ones $1-1.5 \mathrm{~mm}$ long, densely to sparsely covered with appressed hairs; flower buds (broadly) ovoid, slightly pointed; sepals free to basally connate, ovate-triangular to broadly so, 3-6 by $3-5 \mathrm{~mm}$, initially appressed, soon patent and apically reflexed, outer side densely to rather densely covered with appressed hairs; petals green to yellow in vivo, equal, ovate, $5-15$ by $3-8 \mathrm{~mm}$, to 18 by $12 \mathrm{~mm}$ when ripe, outer side densely covered with appressed to erect hairs; stamens 1-1.5 mm long, connective shield densely papillate-hairy. Monocarps 10-15, black in vivo, brownish black in sicco, ellipsoid, 7-13 by 3-7 mm, sparsely covered with appressed hairs when young, soon glabrous, apex rounded to bluntly apiculate (apiculum $<0.5 \mathrm{~mm}$ long), wall $1-1.5 \mathrm{~mm}$ thick, stipes 0-2 by $1.5-2 \mathrm{~mm}$. Seed (juvenile) c. $8 \mathrm{~mm}$ long.

Distribution - Western Amazonian Brazil (Acre) and Peru (San Martín).

Habitat \& Ecology - In campina or campinarana vegetation, or in primary forest, on white, humous sand. At elevations of 200-1200 m. Flowering: June, October, November; fruiting: December.

Notes - Guatteria arenicola is a small-leaved species from the white sand campina or campinarana vegetations in Brazil (Acre), and forests on white sand in Peru (San Martín). It is quite noteworthy by its tiny, prominently veined, coriaceous leaves, and its very small flowers, which have strongly recurved pedicels. Another characteristic of this species is the presence of bark with an orange slash, a feature not seen in any other representative of the genus Guatteria.

Guatteria arenicola has been compared with G. rupestris Mello-Silva \& Pirani, a species which is known from the cerrados in Minas Gerais, Brazil. They both share some leaf characteristics, but in G. rupestris, the leaves mostly have a rounded to even emarginate apex, whereas the basal margins are revolute.

Selection of other specimens examined:

BRAZIL. Acre: Mun. Cruzeiro do Sul, BR-307, road to fazenda of Mr. Idelfonso, $60 \mathrm{~km}$ from Cruzeiro do Sul, 11 November 1991, Cid et al. 10699 (NY, U).

PERU. San Martín: Estación 'Biodiversidad', km 20 on road from Tarapoto to Yurimaguas, $1010 \mathrm{~m}$, 7 December 2003, Pirie et al. 166 (F, HAO, K, MO, OWU, U, USM); Prov. Rioja, Distr. Pardo Miguel, $1 \mathrm{~km}$ E of Centro Poblado Aguas Verdes, road to Perla del Mayo, 28 June 1999, SánchezVega et al. $9908(\mathrm{U})$.

2. Guatteria argentea Erkens \& Maas, spec. nov. - Fig. 2; Map 2

Foliis obovatis supra dense verruculosis et indumento argenteo distincta. - Typus: Monsalve B. 1262 (holo U; iso CUVC, MO), Colombia, El Valle, Bajo Calima, Concesión Pulpapel/Buenaventura, 100 m, 13 November 1986.

Tree 6-12 m tall; young twigs densely covered with appressed, silvery hairs, soon glabrous. Leaves: petiole $8-10 \mathrm{~mm}$ long, $2 \mathrm{~mm}$ diam.; lamina obovate (to narrowly so), $9-12$ by $3.5-5 \mathrm{~cm}$ (leaf index $2-2.5$ ), coriaceous, densely verruculose, slightly shiny dark brown above, brown below, glabrous above, densely covered with appressed, silvery hairs below, base attenuate, apex shortly acuminate (acumen 2-5 mm long), primary vein impressed above, keeled below, secondary veins distinct, $9-13$ on either side of primary vein, prominent above, smallest distance between loops and margin 


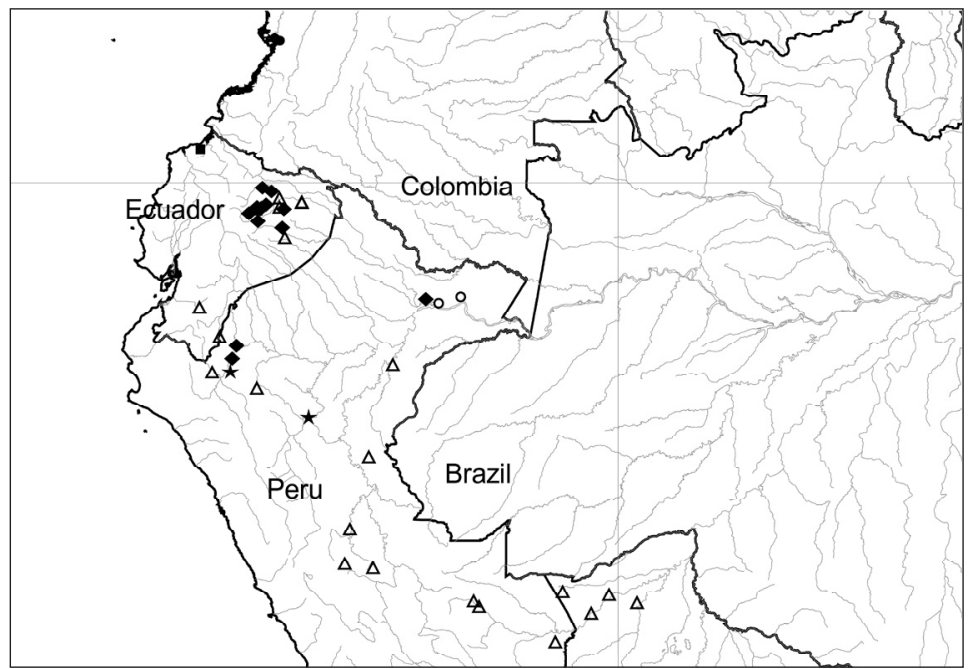

Map 2. Distribution of Guatteria argentea Erkens \& Maas (•), G. brevipetiolata Maas \& Westra (ם), G. confusa Maas \& Westra $(\diamond), G$. duodecima Maas \& Westra $(\triangle)$, G. fractiflexa Maas \& Westra $(\star)$, G. grandipes Maas \& Westra (○).

3-4 mm. Flowers in leaf axils, solitary; pedicels 5-8 mm long, 1-2 mm diam., fruiting pedicels $10-15 \mathrm{~mm}$ long, $2 \mathrm{~mm}$ diam., densely to rather densely covered with appressed, silvery hairs, articulated at 1/3-1/2 from the base, bracts 3 or 4 , the upper one c. 4 by $3 \mathrm{~mm}$, soon falling off; flower buds depressed ovoid; sepals free, broadly ovate-triangular, 3-5 by 4-6 mm, appressed, outer side densely covered with appressed, silvery hairs; petals yellowish green in vivo, subequal, outer ones elliptic to obovate, 9-13 by $5-8 \mathrm{~mm}$, outer side densely covered with appressed, silvery hairs; stamens $1-1.5 \mathrm{~mm}$ long, connective densely hairy. Monocarps $10-15$, green in vivo, brown to blackish in sicco, ellipsoid, 13-16 by 5-6 mm, sparsely covered with appressed hairs, apex apiculate (apiculum c. $0.5 \mathrm{~mm}$ long), wall $1-1.5 \mathrm{~mm}$ thick, stipes $4-6$ by $2 \mathrm{~mm}$. Seed ellipsoid, c. 12 by $5 \mathrm{~mm}$, shiny, dark brown, slightly foveolate.

Distribution - Pacific Coast of Colombia (El Valle).

Habitat \& Ecology - In forest ('bosque pluvial tropical'). At elevations of 50100 m. Flowering: February, August, October, November; fruiting: February, August, November.

Notes - Guatteria argentea is very easily recognizable by its silvery indument on many parts of the plant and by its obovate, densely verruculose leaves with an attenuate base.

The type of the present species (Monsalve B. 1262) has been used by Erkens et al. (2007a, b) for a phylogenetic study on Guatteria. However, in these studies this specimen was assigned to $G$. heterotricha $\mathrm{R}$.E. Fr. It was placed sister to G. rotundata Maas $\&$ Setten to which it looks quite similar. Guatteria rotundata is from Panama (Panamá and San Blas) and the two species share the obovate leaves. Guatteria argentea differs by its dense silvery indument of the young twigs and lower side of the lamina and by its more densely verruculose leaves. 
Selection of other specimens examined:

Colombia. El Valle: Bajo Calima Concesión, 25 km NW of Buenaventura, 9 km NW of San Isidro, 50 m, 12 July 1988, Faber-Langendoen \& Hurtado 1743 (U); Bajo Calima, Concesión Pulpapel/Buenaventura, 100 m, 9 August 1984, Monsalve B. 182 (U).

\section{Guatteria asplundiana R.E.Fr. - Fig. 3; Plate 4; Map 3}

Guatteria asplundiana R.E.Fr. (1959a) 24. - Type: Asplund 19673 (lecto, designated by Maas et al. (1994), S; isolecto P), Ecuador, Pastaza, Mera, near Manguyacu, elevation not recorded, 14 December 1956. This lectotype was chosen from the 2 syntypes, the other being Asplund 18833 (S), Ecuador, Pastaza, Mera, elevation not recorded, 9 March 1956.

Guatteria sp. 10 Chatrou et al. (1997) 111.

Tree 2.5-24 m tall; young twigs rather densely to sparsely covered with appressed and sometimes some erect hairs, soon glabrous. Leaves: petiole 4-12 mm long, 2-4 mm diam.; lamina obovate to ovate, sometimes narrowly so, 7-26 by $4-13 \mathrm{~cm}$ (leaf index 1.5-3.2), coriaceous to chartaceous, not verruculose, blackish brown to dark brown, or greenish brown to greyish brown above, brown to greenish below, sparsely covered with appressed hairs to glabrous above, sparsely to rather densely covered with appressed hairs to glabrous below, base obtuse, acute, or sometimes slightly attenuate, apex acuminate (acumen 5-15 mm long), primary vein impressed above, secondary veins distinct, 11-20 on either side of primary vein, impressed, rarely flat above, smallest distance between loops and margin 1-3 mm. Flowers in a 1-3-flowered inflorescence, in axils of leaves or on leafless branchlets; pedicels 7-20 mm long, 1-2 mm diam., fruiting pedicels to $30 \mathrm{~mm}$ long, 2-4 mm diam., articulation at 1/6-1/2 from the base, sparsely to rather densely covered with appressed hairs to glabrous, upper bract c. $5 \mathrm{~mm}$ long, deciduous; flower buds depressed ovoid; sepals free or basally connate, broadly ovate-triangular, $4-7$ by $5-8 \mathrm{~mm}$, appressed or reflexed, outer side densely to sparsely covered with appressed hairs; petals green to yellow, cream, or reddish in vivo, equal or

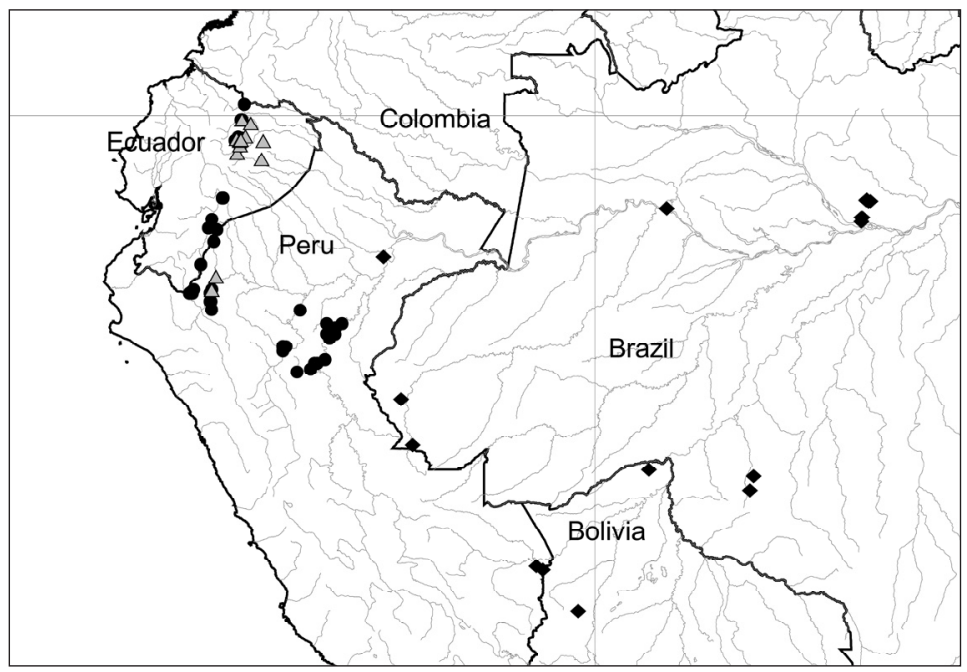

Map 3. Distribution of Guatteria discolor R.E.Fr. $(\diamond)$, G. gentryi Maas \& Erkens $(\triangle)$, G. asplundiana R.E.Fr $(\bullet)$. 


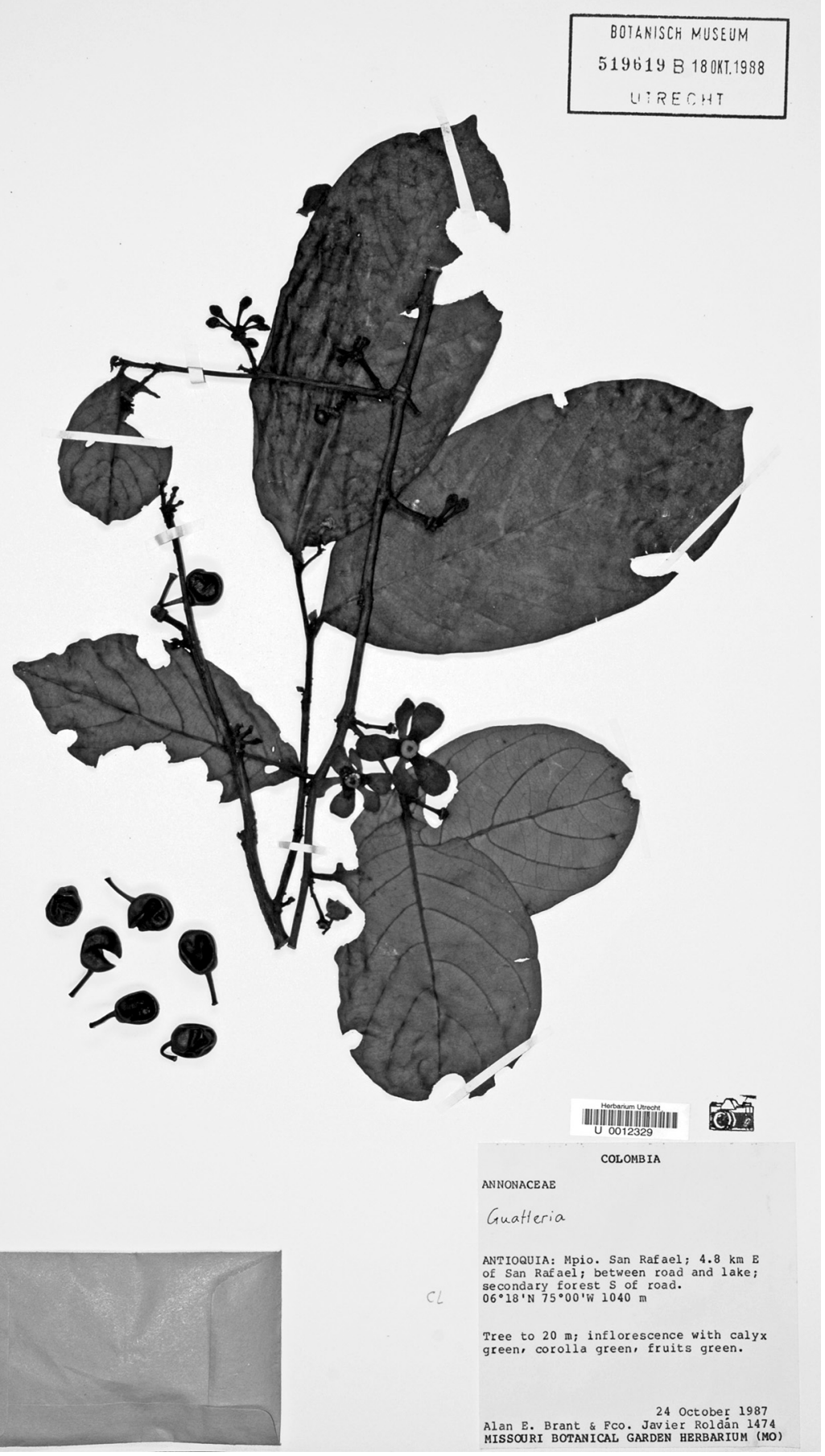




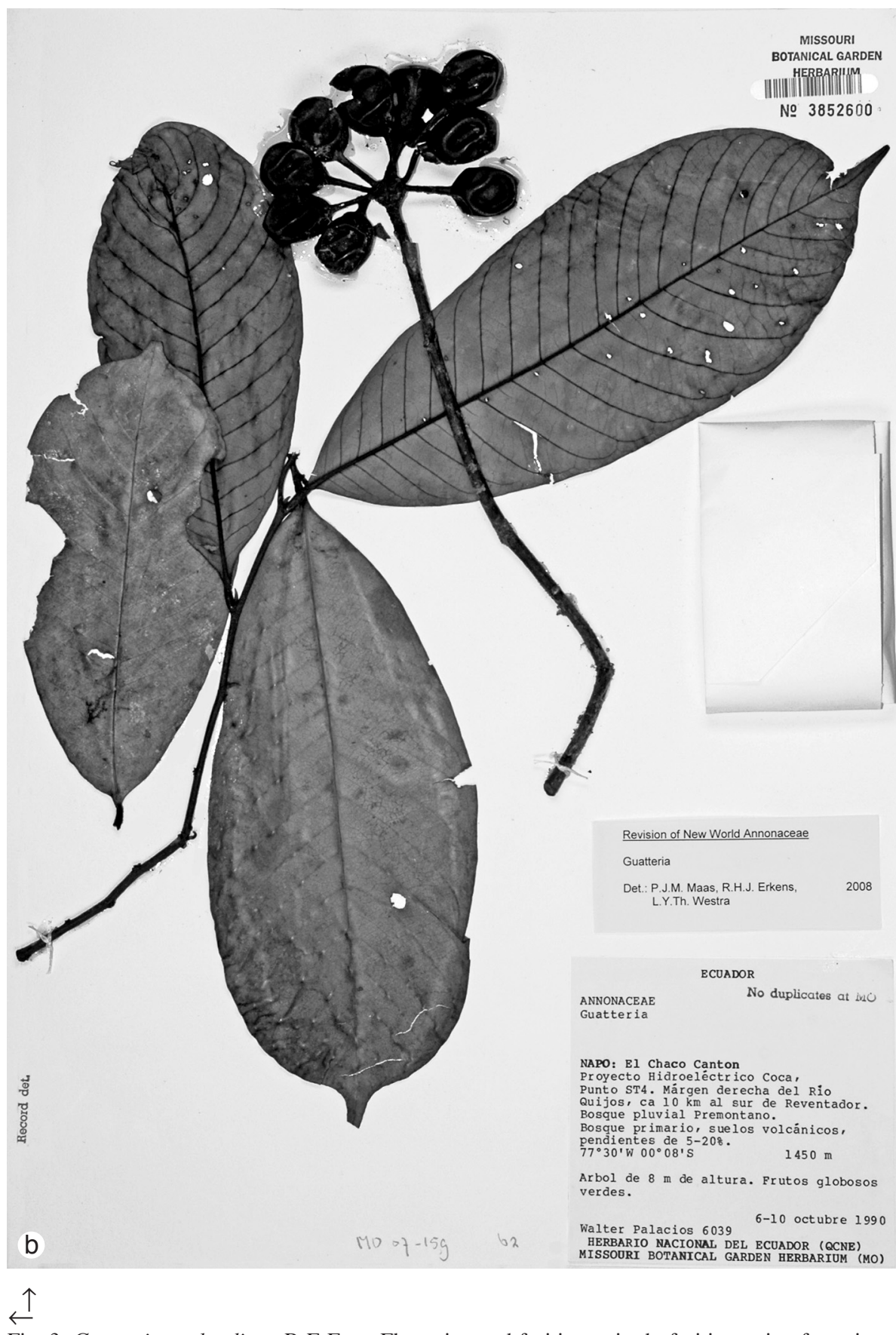

Fig. 3. Guatteria asplundiana R.E.Fr. a. Flowering and fruiting twig; b. fruiting twig of specimen with aberrant monocarps (a: Brant \& Roldán 1474, U; b: Palacios 6039, MO). 
slightly unequal, ovate to obovate, or rhombic, 7-28 by $5-12 \mathrm{~mm}$, outer side densely to sparsely covered with appressed hairs; stamens $1.5-2 \mathrm{~mm}$ long, connective shield papillate to finely hairy, rarely umbonate. Monocarps 5-40, green, maturing purpleblack to black in vivo, brown to blackish in sicco, globose to ellipsoid, 10-20 by 7-15 $\mathrm{mm}$, somewhat wrinkled in sicco, glabrous, apex rounded or apiculate (apiculum $<0.2$ $\mathrm{mm}$ long), wall $0.3-0.5\{-4\} \mathrm{mm}$ thick, stipes $10-20(-30)$ by $1-2\{-3\} \mathrm{mm}$. Seed globose to ellipsoid, $8-12$ by $5-8 \mathrm{~mm}$, dark to pale brown, surface slightly foveolate.

Distribution - Colombia (Antioquia) and Amazonian Ecuador and Peru.

Habitat \& Ecology - In premontane or montane forest. At elevations of 300$2300 \mathrm{~m}$. Flowering and fruiting: throughout the year.

Vernacular names and uses - Colombia: Cargadero, Garrapato. 'Usado para sacar guasca (fibra)'. Peru: Yaïs.

Notes - Guatteria asplundiana has a fruit which resembles that of some species of Unonopsis. It is particularly characterized by its relatively large monocarps, which are, moreover, often wrinkled after drying, probably due to the fact that the seeds are much smaller than the monocarps.

Some material collected in the Ecuadorian state of Napo (named 'Guatteria sp. 10, large monocarps' by Chatrou et al. (1997)) is aberrant in having larger than average monocarps $(17-35$ by $17-30 \mathrm{~mm})$ and seeds $(10-14$ by $8-14 \mathrm{~mm})$, and a thicker monocarp wall $(0.5-1 \mathrm{~mm})$. As all leaf and flower characters fall within the range of variability of $G$. asplundiana we have refrained from giving this material a status of its own. It is cited under a separate heading and in the identification list this material is printed in bold type.

Selection of other specimens examined:

Colombia. Antioquia: Mun. San Rafael, 4.8 km E of San Rafael, 1040 m, 24 October 1987, Brant \& Roldán 1474 (MO, U); Mun. Frontino, Murrí, 20-28 km from Nutibara, 1050-1350 m, 3 November 1988, McPherson et al. 12992 (U); Mun. Frontino, Corregimiento Nutibara, Basin of Río Cuevas, 1940 m, 13 January 1987, Sánchez et al. 896 (U).

ECUADOR. Morona-Santiago: 8 km E of Limón on road to La Unión, 1400-1500 m, 22 April 1985, Harling \& Andersson 24410 (U). Zamora-Chinchipe: Cordillera del Cóndor, basin of Río Nangaritza, Lomas de Chamico, 1450 m, 26 February 2003, Quizhpe et al. 594 (MO, U).

PERU. Amazonas: Prov. Bagua, Distr. Imaza, Putuim, trail to Cerro de Putuim, 400 m, 28 November 2003, Pirie et al. 122 (U). Cajamarca: Prov. San Ignacio, San José de Lourdes, trail to Cerro Picorana, 2000-2200 m, 23 February 2000, Campos et al. 6520 (U).

Selection of aberrant material with larger monocarps:

ECUADOR. Napo: Cantón Archidona, community of Pacto Sumaco, 1550-1600 m, 23 April 1997, Alvarez et al. 1900 (MO, U); Parroquia Cotundo, Huamaní, road from Hollín to Loreto, 1200 m, 26 August 1988, Hurtado et al. 145 (U); Cantón Archidona, foothills S of Volcán Sumaco, km 31 of road from Hollín to Loreto, Challuayacu, 1200 m, 20-25 March 1989, Palacios 4104 (MO, U); Cantón El Chaco, Proyecto Hidroeléctico Coca, Punto ST 4, right bank of Río Quijos, $10 \mathrm{~km} \mathrm{~S}$ of Reventador, 1450 m, 6 October 1990, Palacios 5973 (MO).

\section{Guatteria brevipetiolata Maas \& Westra, spec. nov. - Fig. 4; Map 2}

Species foliis brevipetiolatis basi obliquis, et floribus longepedicellatis distincta. - Typus: T.D. Pennington et al. 14941 (holo U, 2 sheets; iso K), Ecuador, Esmeraldas, Anchayacu, Eloy Alfaro, Mayronga, 100-250 m, 14 April 1994.

Guatteria sp. 5 Chatrou et al. (1997) 110. 


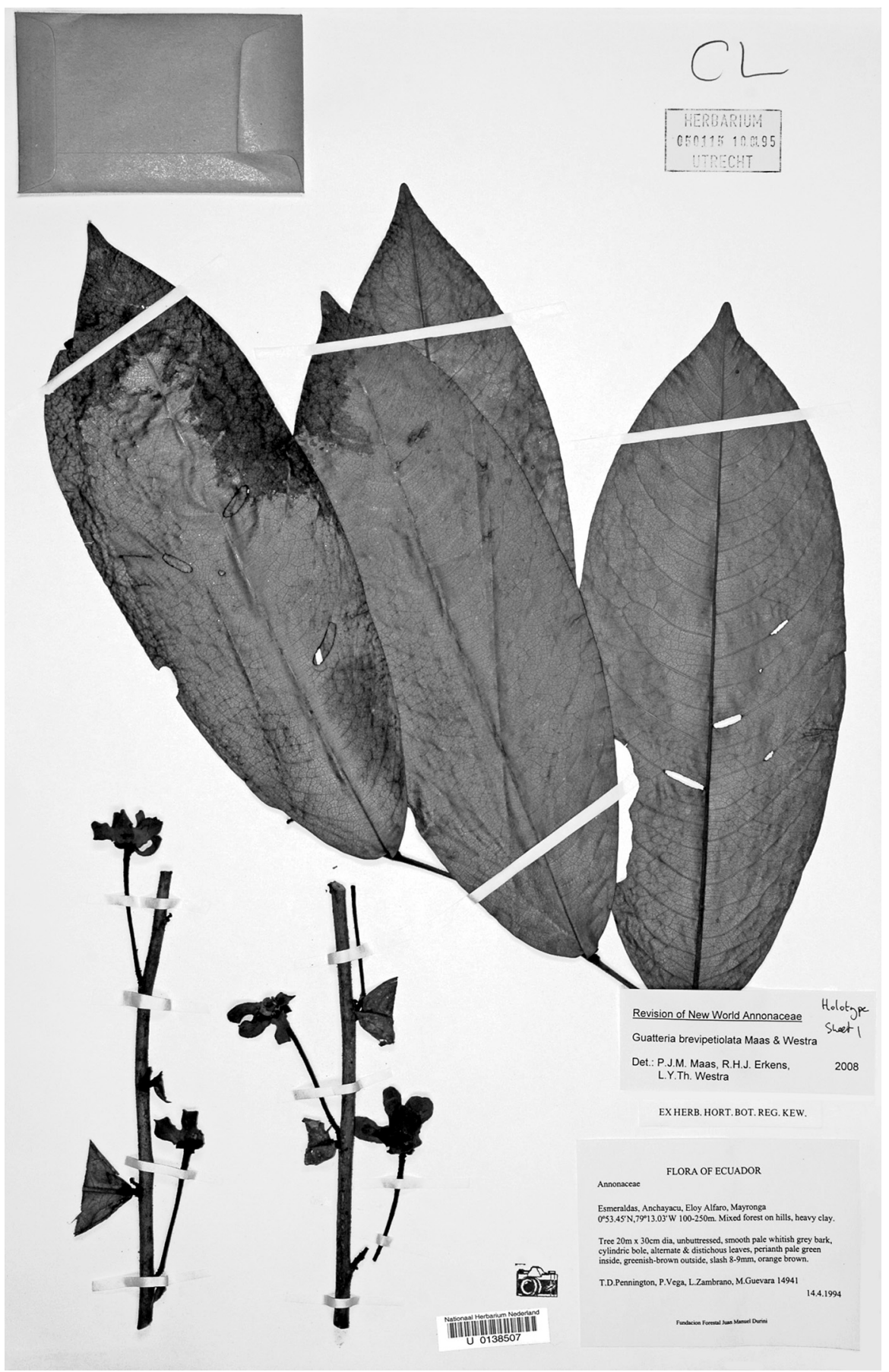

Fig. 4. Guatteria brevipetiolata Maas \& Westra. Flowering twig (T.D. Pennington et al. 14941, holo part $1, \mathrm{U})$. 


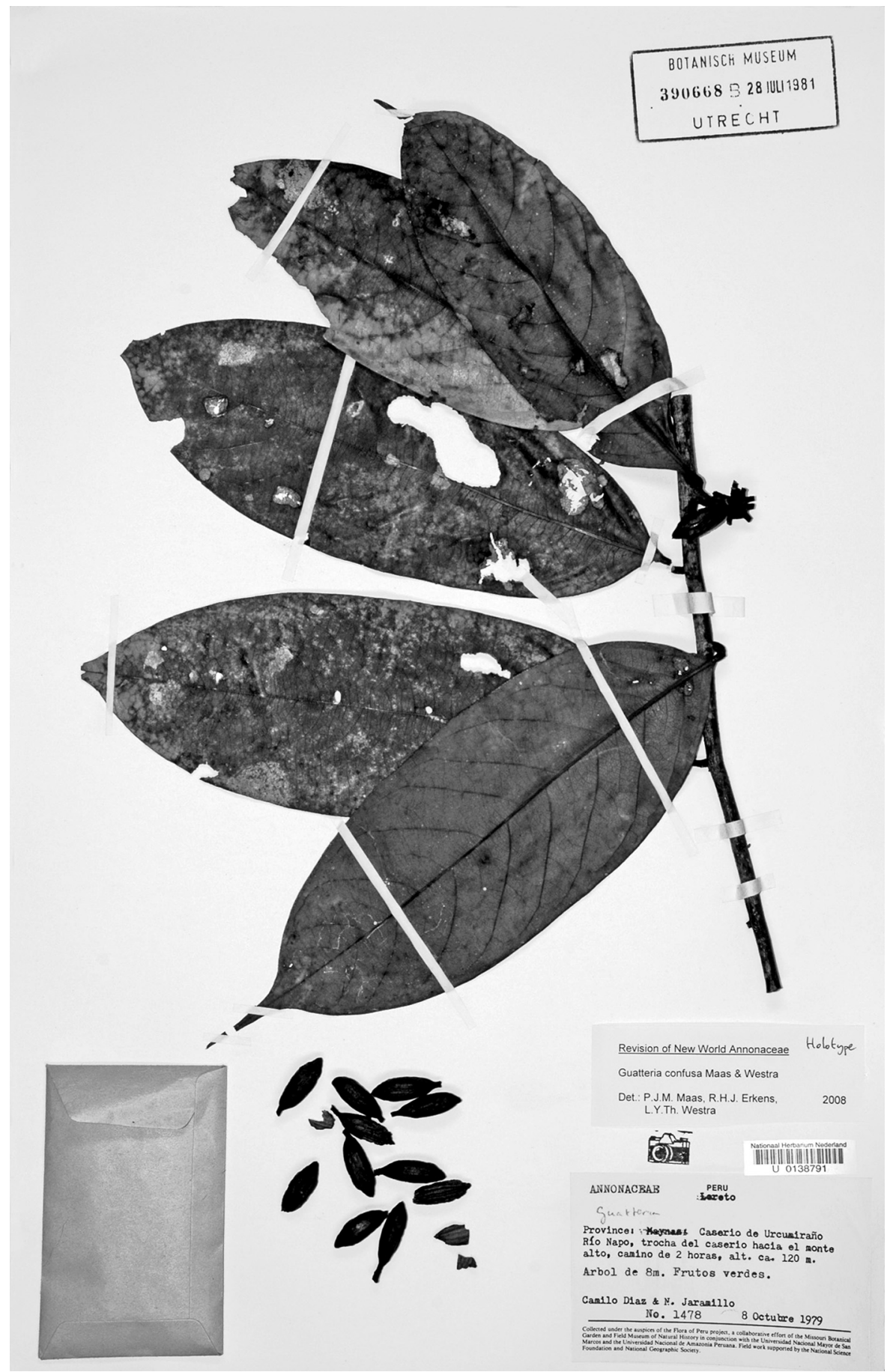

Fig. 5. Guatteria confusa Maas \& Westra. Fruiting twig (Díaz \& Jaramillo 1478, holo U). 
Tree c. $20 \mathrm{~m}$ tall, $30 \mathrm{~cm}$ diam., slash orange-brown; young twigs densely covered with erect and appressed, pale brown, somewhat curly hairs. Leaves: petiole $2-4 \mathrm{~mm}$ long, 2-3 mm diam.; lamina narrowly oblong-elliptic to narrowly elliptic, 17-27 by 7.5-10 $\mathrm{cm}$ (leaf index 2.6-2.9), chartaceous, not verruculose, shiny, green above, green below, sparsely covered with erect and appressed, pale brown, somewhat curly hairs above, rather densely so below, base obtuse, oblique, apex acute to shortly and very gradually, bluntly acuminate (acumen 5-10 mm long), primary vein impressed above, secondary veins distinct, $10-15$ on either side of primary vein, prominent above, smallest distance between loops and margin 2-3 mm. Flowers in axils of leaves or on older branchlets, solitary; pedicels 40-55 mm long, 1-2 mm diam., articulated at 1/10-1/6 from the base, with 4-6 minute bracts below articulation, densely to rather densely covered with erect and appressed, pale brown, somewhat curly hairs; flower buds not seen; sepals free, ovate, c. 6 by $4 \mathrm{~mm}$, patent to reflexed, outer side densely covered with appressed hairs; petals pale green inside, greenish brown outside in vivo, unequal, outer ones oblong-elliptic, $13-16$ by $5-7 \mathrm{~mm}$, inner ones elliptic to elliptic-oblong, 13-20 by 7-11 mm, outer side densely covered with (mostly) appressed hairs; stamens c. $2 \mathrm{~mm}$ long, connective shield finely papillate-hairy to subglabrous. Monocarps and seeds not seen.

Distribution - Western Ecuador (Esmeraldas).

Habitat \& Ecology - In mixed forest on hills, on heavy clay. At elevations of 100-250 m. Flowering: April; fruiting: unknown.

Note - Guatteria brevipetiolata can be recognized at first glance by the combination of the following characteristics: a short petiole, an oblique and obtuse leaf base, a bluntly and shortly acuminate to acute leaf apex, and long-pedicellate flowers.

\section{Guatteria confusa Maas \& Westra, spec. nov. - Fig. 5; Map 2}

Species foliis pro ratione paucinerviis, monocarpiis et seminibus distincte apiculatis facile recognescenda. - Typus: Díaz \& Jaramillo 1478 (holo U; iso K, MO), Peru, Loreto, Prov. Maynas, Caserio de Urcumiraño, Río Napo, 120 m, 8 October 1979.

Tree 5-12 m tall; young twigs sparsely covered with appressed hairs, soon glabrous. Leaves: petiole $8-10 \mathrm{~mm}$ long, $2-3 \mathrm{~mm}$ diam.; lamina narrowly elliptic, $17-24$ by 5-9 cm (leaf index 2.9-3.4), coriaceous, not verruculose, shiny, blackish green above, pale brown below, glabrous above, sparsely covered with appressed hairs to glabrous below, base acute to obtuse, apex acuminate (acumen 10-15 mm long), primary vein, impressed, flat or even slightly raised above, secondary veins distinct, 7-12 on either side of primary vein prominent above, smallest distance between loops and margin 3-5 mm. Flowers in leaf axils, solitary; pedicels c. $3 \mathrm{~mm}$ long, $2 \mathrm{~mm}$ diam., fruiting pedicels c. $15 \mathrm{~mm}$ long, 3-4 $\mathrm{mm}$ diam., articulation indistinct, densely covered with appressed, brown hairs in flower, glabrous in fruit; flower buds depressed ovoid; sepals free, broadly ovate-triangular, $5-6$ by $5-6 \mathrm{~mm}$, appressed, outer side densely covered with appressed, brown hairs; petals green in vivo, too young to be measured, outer side densely covered with appressed, brownish white hairs; stamens not seen. Monocarps c. 20, green in vivo, black in sicco, ellipsoid, 19-23 by $8-9 \mathrm{~mm}$, longitudinally wrinkled in sicco, glabrous, apex apiculate (apiculum 1-3 $\mathrm{mm}$ long), wall 0.5-0.7 $\mathrm{mm}$ thick, stipes $3-5$ by $1-2 \mathrm{~mm}$. Seed ellipsoid, $15-20$ by $8 \mathrm{~mm}$, dark brown, apex distinctly apiculate (apiculum 1-2 mm long), rugose. 


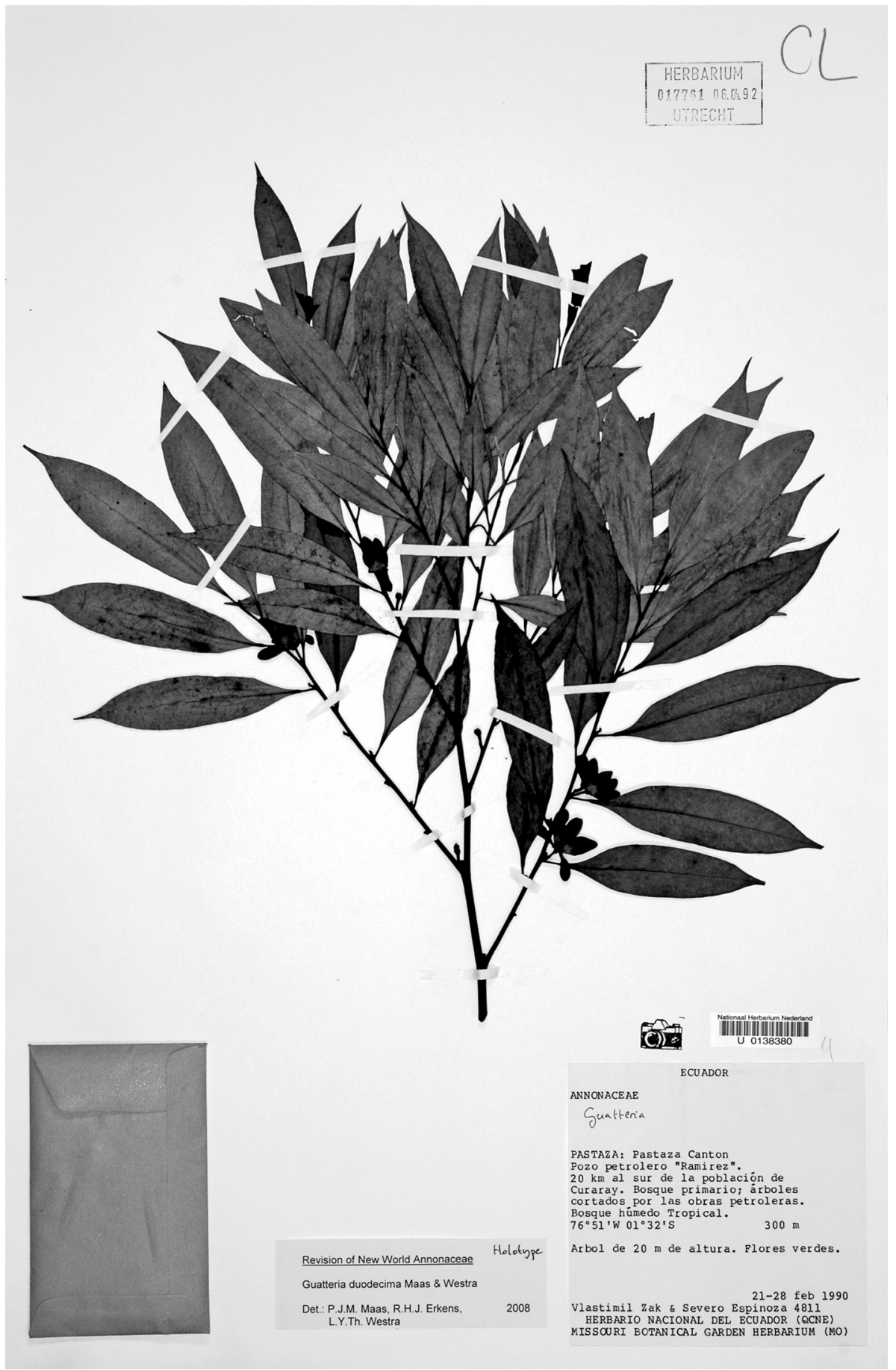

Fig. 6. Guatteria duodecima Maas \& Westra. Flowering twig (Zak \& Espinoza 4811, holo U). 
Distribution - Amazonian Peru (Loreto).

Habitat \& Ecology - In non-inundated forest, on clayey soil. At elevations of 120$140 \mathrm{~m}$. Flowering: November; fruiting: July and October.

Note - In the 'Florula de las Reservas Biológicas de Iquitos, Peru' (Vásquez 1997) mention is made of an Ephedranthus sp. A, accompanied by a short description. Although we were unable to examine the herbarium material we feel certain to judge by the description that Ephedranthus sp. A is identical with our G. confusa. This is the reason why the epithet 'confusa' was chosen.

Other specimens examined:

PERU. Loreto: Prov. Maynas, Iquitos, Buena Suerte, Río Itaya, 17 November 1986, Vásquez \& Jaramillo 8422 (MO, U); Prov. Maynas, Distr. Amazonas, Explornapo Camp, Río Sucusari, 140 m, 28 July 1991, Vásquez \& Grández, 17520 (MO, U).

\section{Guatteria discolor R.E.Fr. - Plate 2; Map 3}

Guatteria discolor R.E.Fr. (1939) 509, f. 33a.

Guatteria discolor can be recognized by slightly pointed flower buds and relatively long (20-25 mm), shortly stipitate monocarps (stipes 2-6 mm long). In the herbarium it can be recognized by thick, 2-coloured leaves with a reddish indument on the lower side.

Distribution - The species was only known so far from Amazonian Brazil (Acre, Amazonas, and Rondônia) and Bolivia (La Paz and Pando), and French Guiana, but it has recently been found in Peru.

Specimens examined:

PERU. Loreto: Río Nanay, 6 vueltas aguas arriba de Iquitos, 28 December 1976, Revilla 2099 (U). Madre de Dios: Tambopata, Tambopata Tourist Camp, at junction of Ríos Tambopata and La Torre, 280 m, 22 July 1985, Gentry et al. 51123 (MO, U).

\section{Guatteria duodecima Maas \& Westra, spec. nov. - Fig. 6; Map 2}

Foliis angustis dense vel sat dense verruculosis subtus pilis appressis dense vel sat dense obtectis (sericeis), floribus breviter pedicellatis et monocarpiis breviter stipitatis distincta. - Typus: Zak \& Espinoza 4811 (holo U; iso AAU, F, K, MO, WU), Ecuador, Pastaza, Cantón Pastaza, Pozo petrolero 'Ramirez', 20 km S of Curaray, 300 m, 21-28 February 1990.

Guatteria sp. 12 Chatrou et al. (1997) 111.

Tree 10-40 m tall, up to $60 \mathrm{~cm}$ diam., one specimen reported with steep buttresses; young twigs densely to sparsely covered with appressed hairs, soon glabrous. Leaves: petiole 5-10 $\mathrm{mm}$ long, $0.5-1 \mathrm{~mm}$ diam.; lamina narrowly elliptic to narrowly oblongelliptic, $8-15$ by $2-5 \mathrm{~cm}$ (leaf index $2.7-4.4$ ), chartaceous, densely to rather densely verruculose, greyish to brown above, brown to greenish brown below, glabrous or sparsely covered with appressed hairs above, densely to rather densely covered with appressed, white, long hairs (sericeous) below, base attenuate, sometimes acute, apex acuminate (acumen 5-10 mm long), primary vein impressed to flat above, secondary veins distinct, 13-20 on either side of primary vein, prominent above, smallest distance between loops and margin 1-3 $\mathrm{mm}$. Flowers in a 1- or 2-flowered inflorescence, in axils of leaves or on leafless branches; pedicels 5-10 mm long, 0.5-1\{-2\} mm diam., fruiting pedicels to $25 \mathrm{~mm}$ long, 2-3 mm diam., articulated at 1/4-2/3 from the base, 
bracts $3-5$ below articulation, the upper one $3-3.5$ by $1.5-2 \mathrm{~mm}$, soon falling off, densely covered with appressed hairs; flower buds broadly ovoid; sepals free, broadly ovate-triangular, $2-4$ by $2-4 \mathrm{~mm}$, appressed, soon becoming reflexed, outer side densely covered with appressed, white hairs; petals green in vivo, maturing brownish yellow, subequal, narrowly oblong-elliptic to narrowly rhombic-ovate, $10-18$ by $4-7$ $\mathrm{mm}$, outer side densely covered with appressed, white hairs; stamens c. $1 \mathrm{~mm}$ long, connective shield papillate. Monocarps 10-40, green, maturing purple-black to black in vivo, brown to black in sicco, ellipsoid, $10-18$ by $6-12 \mathrm{~mm}$, rather densely covered with appressed hairs, apex rounded or bluntly apiculate (apiculum c. $0.5 \mathrm{~mm}$ long), wall $0.5-1 \mathrm{~mm}$ thick, stipes $2-10$ by $1-2 \mathrm{~mm}$. Seed ellipsoid, $10-13$ by $5-6 \mathrm{~mm}$, shiny brown, foveolate and longitudinally grooved.

Distribution - Ecuador, Peru, Bolivia, Brazil (Acre).

Habitat \& Ecology - In non-inundated forest (from lowland rain forest to premontane forest), sometimes in periodically inundated forest. At elevations of 150-1800 m. Flowering: throughout the year; fruiting: from May to November.

Vernacular names - Bolivia: Piraquina, Oyshobo (Yuracare). Peru: Atzmiriqui.

Notes - Guatteria duodecima can at first glance be distinguished by relatively narrow and verruculose leaves, usually narrowed both toward the base and toward the apex, and densely to rather densely covered with appressed, almost silvery hairs on the lower side. Other distinctive features of this species are found in the shortly pedicellate flowers and monocarps which are always longer that the stipes.

It is named duodecima or 'twelfth' in reference to Chatrou et al. (1997) who lists this as unidentified species and given number 'sp. 12'.

Flowers of G. duodecima reportedly have an apple-like odor (Korning \& Thomsen 47656).

The lower side of the leaves is mentioned as having a silvery shine (Chatrou et al. 25).

Selection of other specimens examined:

BRAZIL. Acre: Fazenda Bom Sossego, between Igarapé do Cujubim and Igarapé Jacamin, 27 September - 7 October 1985, Campbell et al. 8817 (U).

ECUADOR. Orellana: Añangu, Parque Nacional Yasuní, 300-365 m, 24-25 January 1985, Øllgaard et al. 57186 (U). Pastaza: Cantón Pastaza, Pozo petrolero 'Ramirez', 20 km S of Curaray, 300 m, 21-28 February 1990, Zak \& Espinoza 5057 (MO, U).

Peru. Madre de Dios: Parque Nacional del Manu, Maizal, 23 November 1994, Chatrou et al. 25

(U). San Martín: Rioja-Pomacochas Road, below Venceremos, c. 20 km NW of Rioja near Restaurant El Amigo, 1600 m, 8 February 1984, Gentry \& Smith 45155 (U).

Bolivia. Cochabamba: Prov. Carrasco, El Volcán, 7 km from Bulo-Bulo, 1 September 1991, Cornejo et al. 26 (U). La Paz: Prov. Larecaja, Copacabana, 10 km S of Mapiri, 850-950 m, 8 October - 15 November 1939, Krukoff 11095 (MO, U).

8. Guatteria flabellata Erkens \& Maas, spec. nov. - Fig. 7; Plate 2; Map 1

Species foliis basi cordatis vel obtusis, venis supra impressis, petalis flabellatis et conspicue venosis facile recognoscenda. - Typus: Maas et al. 6297 (holo U, 2 sheets; iso K, MO, WIS), Peru, Loreto, Prov. Maynas, Río Momón, 0-5 km above confluence with Río Nanay, 100 m, 15 November 1984.

Guatteria sp. A Vásquez (1997) 100. 


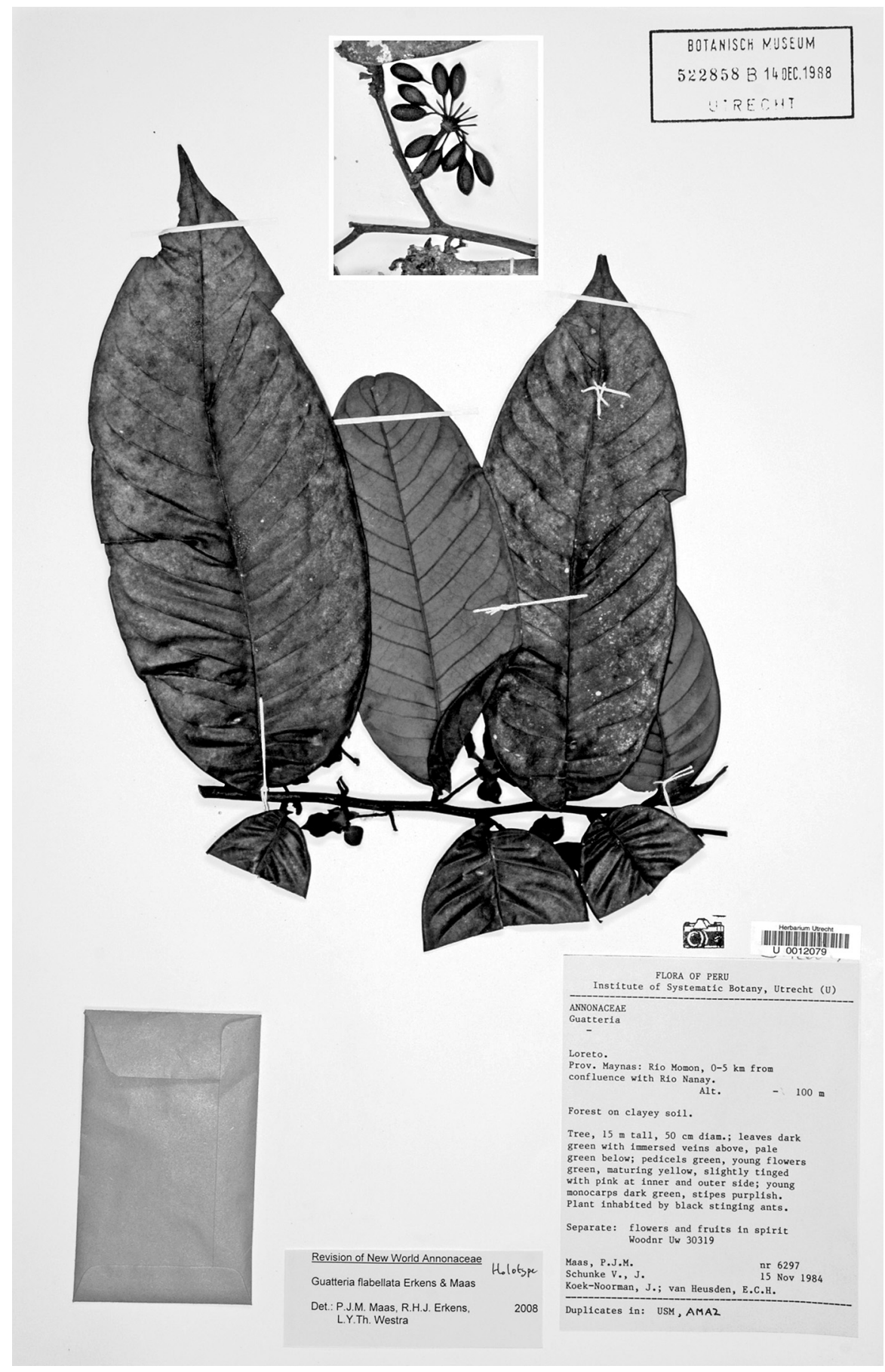

Fig. 7. Guatteria flabellata Erkens \& Maas. Flowering twig; inset: fruiting twig (Maas et al. 6297, holo part 1, U; inset: idem, holo part 2, U). 
Tree (3-)5-28 m tall, to $60 \mathrm{~cm}$ diam.; young twigs sparsely covered with appressed hairs, soon glabrous. Leaves: petiole $8-12(-15) \mathrm{mm}$ long, 3-5 mm diam.; lamina narrowly elliptic, $20-38$ by $7-16 \mathrm{~cm}$ (leaf index 1.6-3.3), coriaceous, not verruculose, dull, brown above and below, glabrous above, sparsely to rather densely covered with appressed, very short hairs below, base cordate to obtuse, apex acuminate (acumen $10-25(-35) \mathrm{mm}$ long), primary vein impressed above, secondary veins distinct, 14-22 on either side of primary vein, impressed above, tertiary veins subparallel, smallest distance between loops and margin 3-5 mm. Flowers in axils of leaves or on leafless branches, in a 1-3-flowered inflorescence; pedicels 15-25 mm long, 1-2 mm diam., fruiting pedicels c. $25 \mathrm{~mm}$ long, $2 \mathrm{~mm}$ diam., densely to sparsely covered with appressed, brown hairs, articulated at c. 1/5 from the base; flower buds depressed ovoid; sepals free, ovate-triangular, 5-9 by $4-7 \mathrm{~mm}$, strongly reflexed, outer side densely covered with appressed, brown hairs; petals green, maturing cream to reddish in vivo, subequal, broadly obovate, $25-40\{-50\}$ by $15-25\{-40\} \mathrm{mm}$, base distinctly narrowed (unguiculate) and margins rolled outwards, apex often emarginate, outer base densely covered with appressed hairs, middle and apical part sparsely so to glabrous, outer side with distinct, impressed veins; stamens 1-2 mm long, connective shield papillate-hairy. Monocarps 50-75, green, maturing red to black in vivo, black in sicco, ellipsoid, 9-15 by $5-8 \mathrm{~mm}$, sparsely covered with some appressed hairs, apex apiculate (apiculum $<0.5 \mathrm{~mm}$ long), wall $0.2-0.4\{-1\} \mathrm{mm}$ thick, stipes $8-16$ by $0.5-1\{-1.5\} \mathrm{mm}$. Seed ellipsoid, $8-14$ by $5-7 \mathrm{~mm}$, pale to dark brown, foveolate.

Distribution - Amazonian Peru (Loreto), adjacent Brazil (Amazonas, Rondônia).

Habitat \& Ecology - In temporally inundated (igapó, restinga baja, tahuampa, várzea) forest, rarely in non-inundated forest. At elevations of $0-160 \mathrm{~m}$. Flowering: April to December; fruiting: April to November.

Vernacular names - Peru: Anona, Anonilla, Anonilla-carahuasca, Carahuasca, Carahuasca blanca, Carahuasca de bajial, Carahuasca de hoja ancha.

Note - It is quite amazing that G. flabellata has never been described before as it is well collected and as it has very distinct differentiating characters. It is quite noteworthy by its large, thick, brown drying leaves, with the veins impressed above and with a cordate to obtuse base; the petals are very well marked by the quite distinct impressed venation at their outer side; furthermore the petals are distinctly narrowed toward the base (almost clawed), whereas the apex is often somewhat emarginate. The specific epithet refers to the fan-shaped (fan = flabellum) petals.

Selection of other specimens examined:

BRAZIL. Amazonas: Mun. São Paulo de Olivença, 8 km S of main square, 5 December 1986, Daly et al. 4472 (U). Rondônia: Mun. Porto Velho, Reservatório da Usina Hidrelétrica de Samuel, Vicinal PR-1, 11 June 1986, Cid et al. 7421 (U).

PERU. Loreto: Río Itaya, above Iquitos, 15 August 1972, Croat 19183 (MO, U).

\section{Guatteria flagelliflora Maas \& Westra, spec. nov. - Fig. 8; Map 1}

Species unica inter omnes species huius generis nobis cognitis habitu flagelliflori. - Typus: Vásquez et al. 22500 (holo U, 2 sheets), Peru, Amazonas, Prov. Condorcanqui, Distr. El Cenepa, Mamayaque, Río Cenepa, Cerro Sakee gaig, 900-1000 m, 12 February 1997.

Tree c. $25 \mathrm{~m}$ tall; young twigs sparsely covered with appressed hairs, soon glabrous, black. Leaves: petiole c. $10 \mathrm{~mm}$ long, $2 \mathrm{~mm}$ diam.; lamina narrowly elliptic to narrowly 


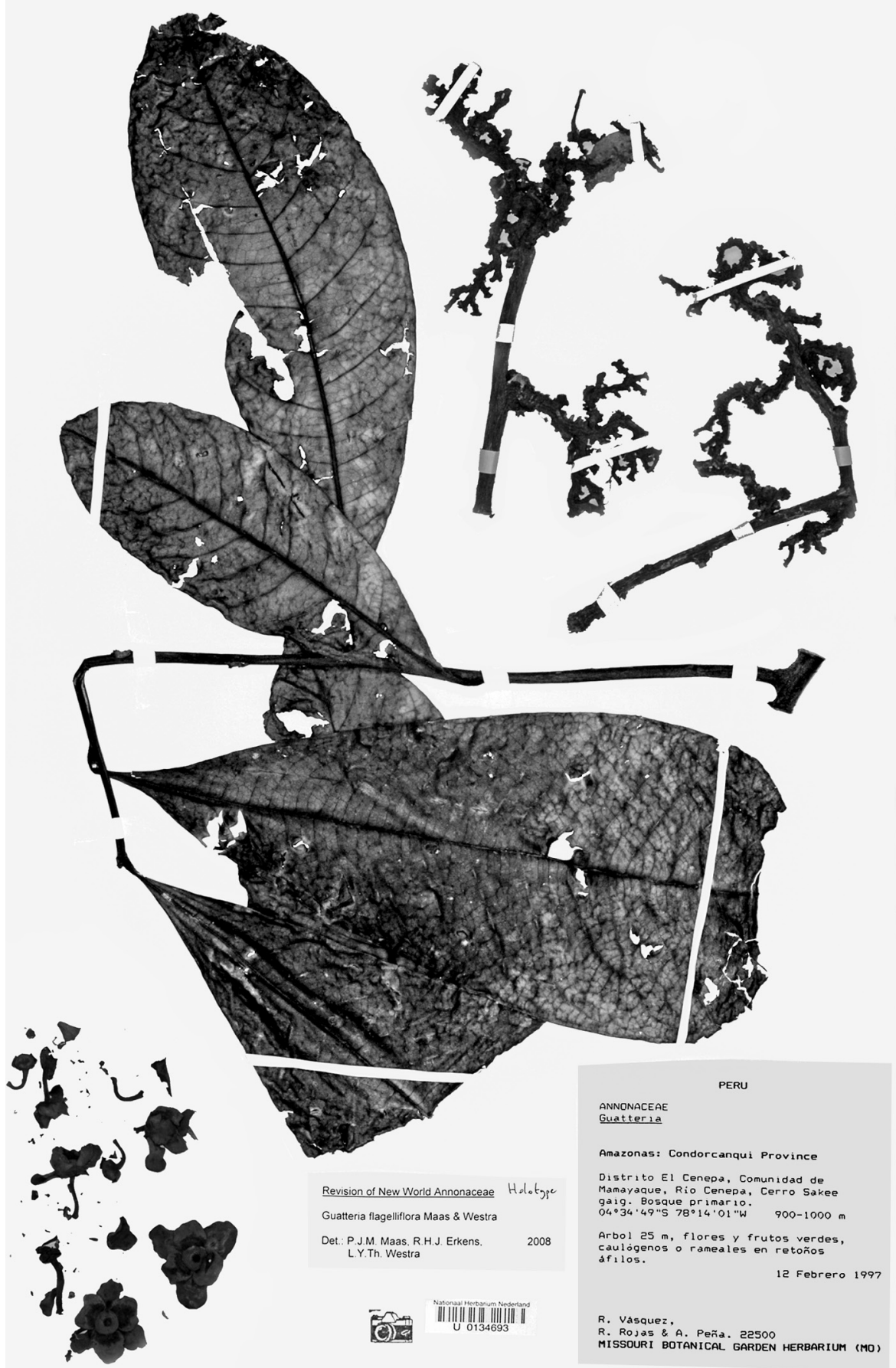

Fig. 8. Guatteria flagelliflora Maas \& Westra. Flowering and fruiting twigs (Vásquez et al. 22500, holo part 1, U; inset: idem, holo part 2, U). 

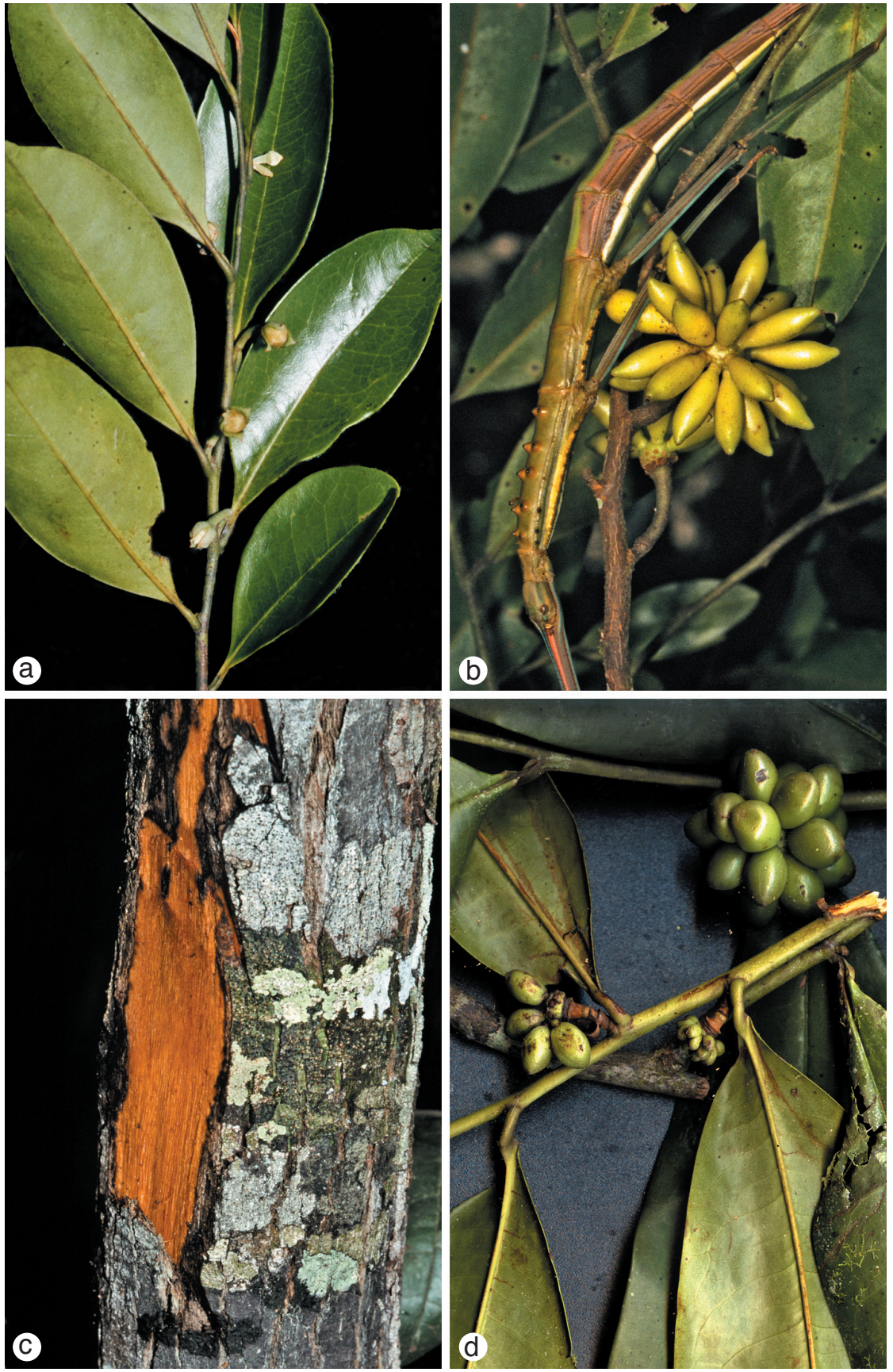

Plate 1. a-c. Guatteria arenicola Maas \& Erkens; d. G. pastazae R.E.Fr. - a. Flowering twig; b. fruiting twig; c. bark slash; d. fruiting twig (a: Maas et al. 8980; b: Pirie et al. 166; c: Maas et al. 8980; d: Homeier 1570). - Photos: a, c by P.J.M. Maas; b by M. Botermans and R. van Velzen; d by J. Homeier. 

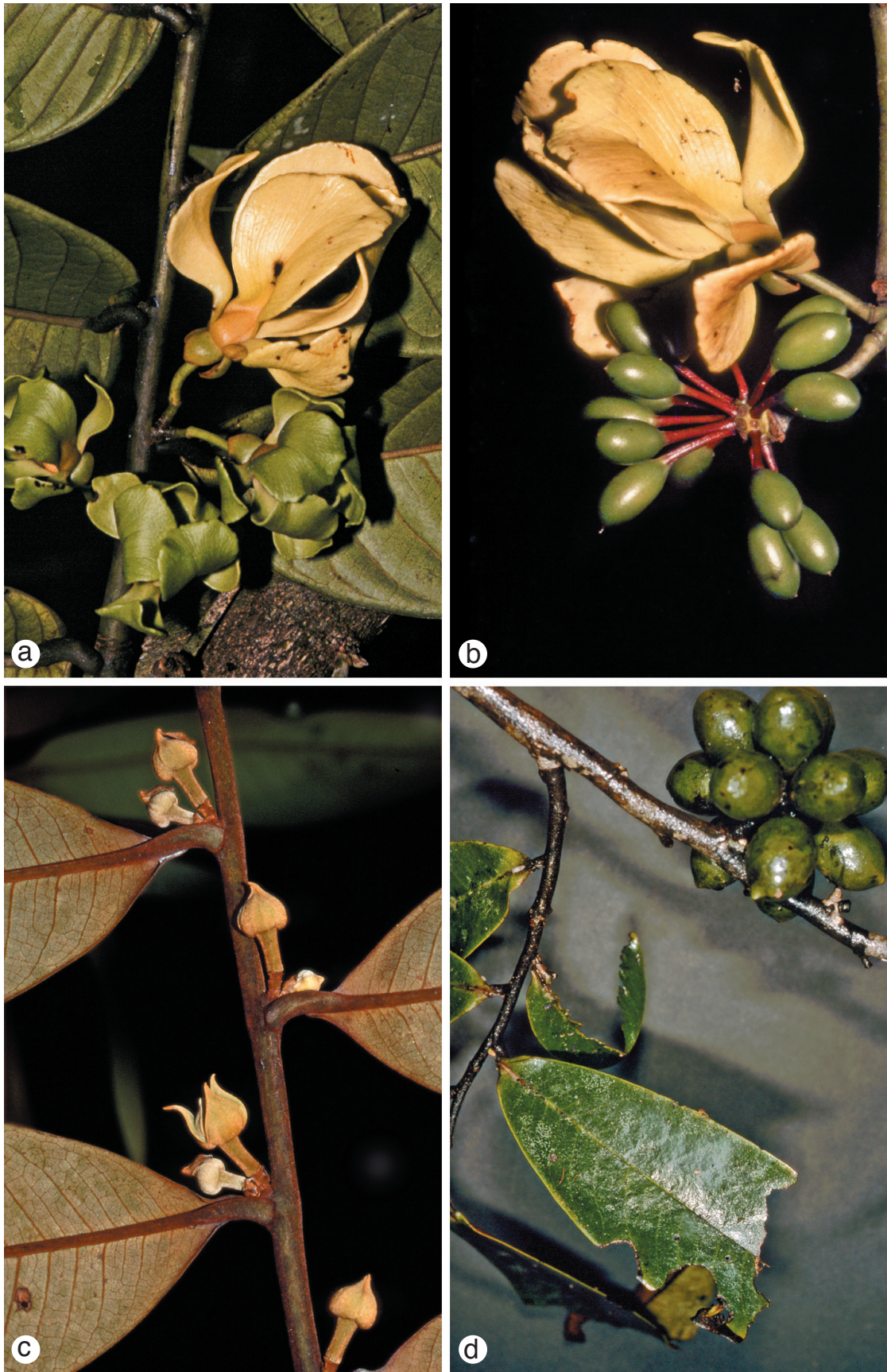

Plate 2. a, b. Guatteria flabellata Erkens \& Maas; c, d. G. discolor R. E.Fr. - a. Flowering twig; b. flowering and fruiting twig; c: flower buds; d: fruiting twig (a, b: Maas et al. 6297; c: Miralha et al. 304; d: Maas et al. 1183). - Photos: all by P.J.M. Maas. 


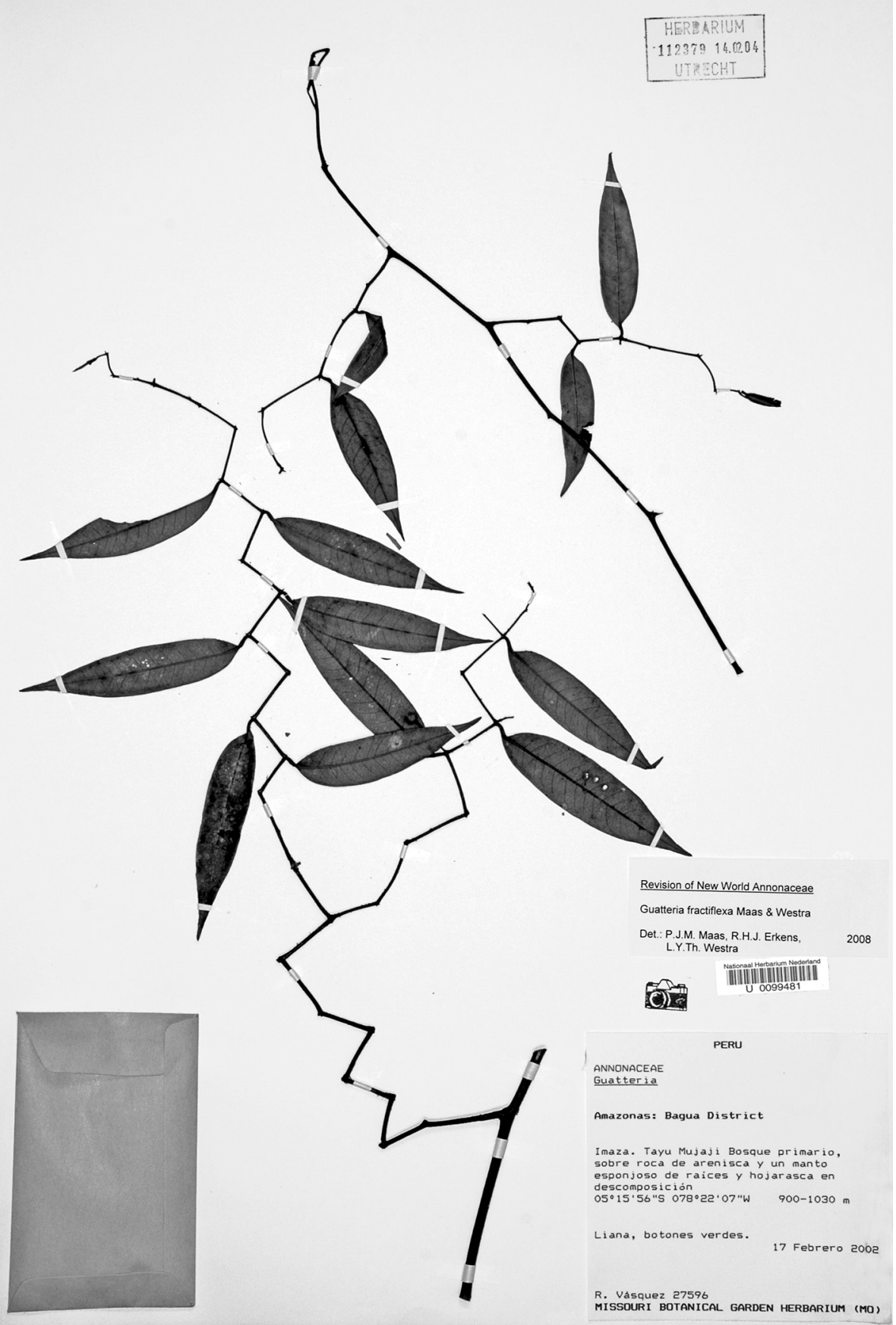

Fig. 9. Guatteria fractiflexa Maas \& Westra. Sterile twig (Vásquez 27596, holo U). 
obovate, $23-32$ by $9 \mathrm{~cm}$ (leaf index 2.6-3.6), chartaceous, not verruculose, blackish brown above, brown below, glabrous above, sparsely covered with appressed hairs below, base long-acute, apex obtuse to acuminate (acumen c. $15 \mathrm{~mm}$ long), primary vein flat above, secondary veins distinct, $12-16$ on either side of primary vein, slightly prominent above, smallest distance between loops and margin $2-4 \mathrm{~mm}$. Flowers in condensed panicle-like inflorescences on leafless sprouts from the stem; (only detached flowers available, data on pedicels provisional); pedicels 15-17 mm long, 1.5 mm diam., young fruiting pedicels $15-25 \mathrm{~mm}$ long, $2 \mathrm{~mm}$ diam., articulated at c. 1/5 from the base, bracts soon falling off, densely covered with appressed hairs; flower buds ovoid; sepals free, broadly ovate, 5-7 by $4-6 \mathrm{~mm}$, appressed, outer side densely covered with appressed hairs; petals green, unequal, outer ones elliptic to ellipticovate, $15-20$ by $10-15 \mathrm{~mm}$, inner ones broadly to very broadly elliptic-ovate, $10-15$ by 10-12 mm, outer side densely covered with appressed hairs; stamens c. $2 \mathrm{~mm}$ long, connective shield finely papillate-hairy. Monocarps $25-50$, black in vivo and in sicco, $8-10$ by $4-5 \mathrm{~mm}$, wrinkled in sicco, glabrous, apex apiculate (apiculum up to $1 \mathrm{~mm}$ long), wall $0.1-0.2 \mathrm{~mm}$ thick, stipes $5-8$ by $1 \mathrm{~mm}$. Seed ellipsoid, $9-10$ by $4-6 \mathrm{~mm}$, strongly tuberculate. .

Distribution - Amazonian Peru (Amazonas).

Habitat \& Ecology - In primary forest. At elevations of 900-1000 m. Flowering and fruiting: February.

Note - Guatteria flagelliflora is unique by its flagellate inflorescence, a feature not reported so far in Guatteria.

\section{Guatteria fractiflexa Maas \& Westra, spec. nov. - Fig. 9; Map 2}

Liana vel frutex scandens ramulis fractiflexis bene recognescenda. - Typus: Christenhusz \& Cárdenas-Ramires 2110 (holo U; iso LZ, TUR, USM), Peru, San Martín, Cerro Guayrapurina, top of the ridge, steep southfacing slope, 1300 m, 14 August 2002.

Liana or creeping shrub; young twigs with a zigzag pattern, sparsely covered with appressed hairs, soon glabrous. Leaves: petiole 3-5 mm long, 1-2 $\mathrm{mm}$ diam.; lamina narrowly elliptic, $6-10$ by $1.5-2.5 \mathrm{~cm}$ (leaf index $3.5-4.5$ ), coriaceous, not verruculose, dull, greyish green above, pale brown below, glabrous above, except for some hairs along primary vein, sparsely covered with appressed hairs below, base acute, apex long-acute, primary vein impressed above, secondary veins indistinct, 13-16 on either side of primary vein, flat above, smallest distance between loops and margin 1-2 mm. Flowers (only one available) in axil of leaf near (aborted) top of branchlet, single; pedicels 15-25 mm long, $1 \mathrm{~mm}$ diam., articulated at 1/4-1/2 from the base, bracts soon falling off, densely covered with appressed, brown hairs; flower buds subglobose; sepals free, broadly ovate, c. 6 by $5.5 \mathrm{~mm}$, outer side densely covered with appressed hairs; petals pale yellow in vivo, narrowly elliptic to narrowly elliptic-obovate, outer ones c. 13 by $5 \mathrm{~mm}$, inner ones c. 15 by $6 \mathrm{~mm}$, outer side densely covered with appressed hairs; stamens c. $1.5 \mathrm{~mm}$ long, connective shield glabrous. Monocarps and seeds not seen.

Distribution - Amazonian Peru (Amazonas, San Martín).

Habitat \& Ecology - In low, primary forest, with many epiphytes, and with a thick layer of moss, roots, and leaves, on sandstone soil. At elevations of 320-1300 m. Flowering: February and August; fruiting: unknown. 

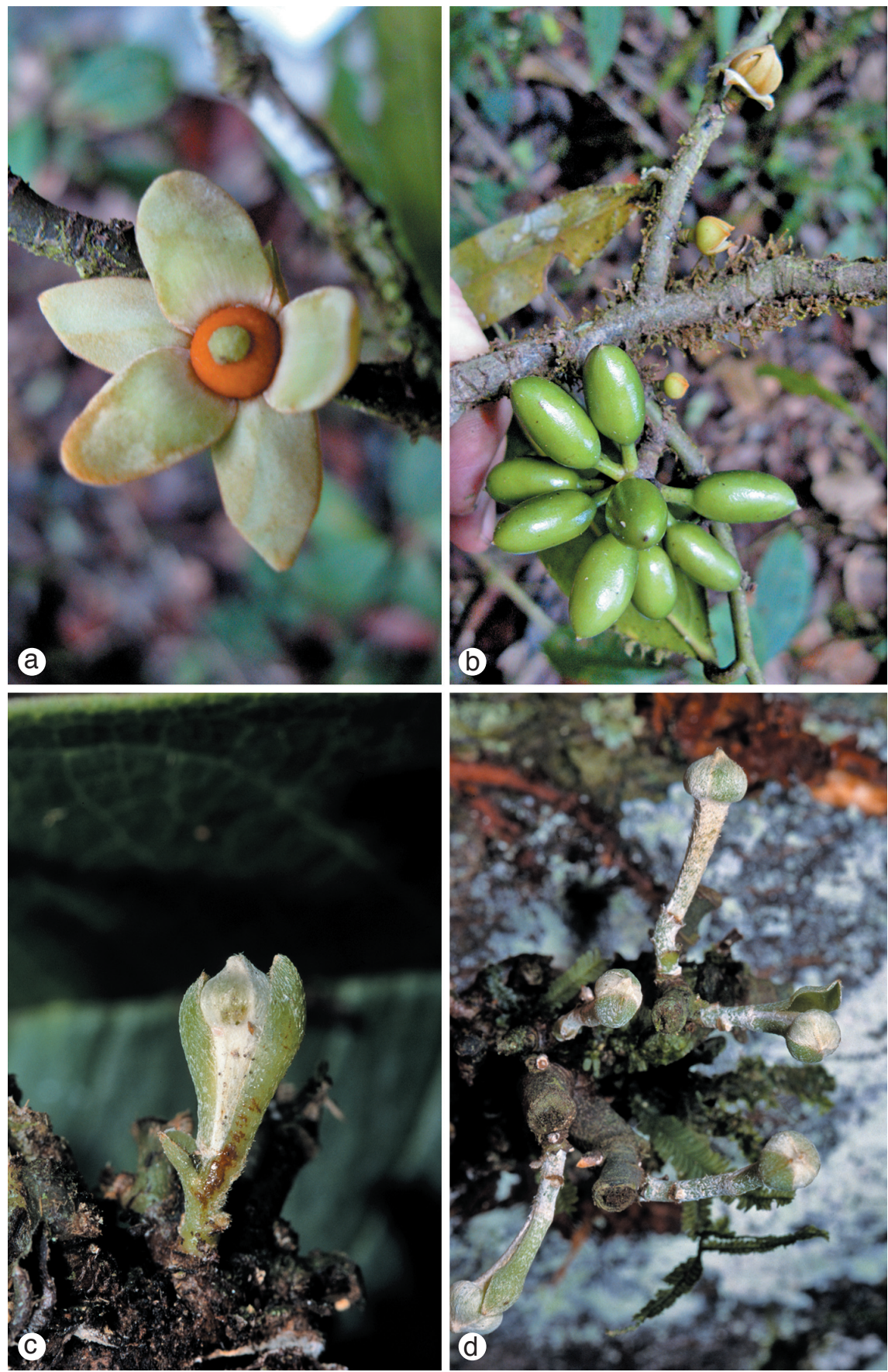

Plate 3. a, b. Guatteria gentryi Maas \& Erkens; c, d. G. scalarinervia D. R.Simpson - a. Flowering twig; b. fruiting and flowering twig; c. flower bud; d. infloresence (a, b: Homeier 3707; c, d: Chatrou et al. 174). - Photos: a, b by J. Homeier; c, d by L.W. Chatrou. 

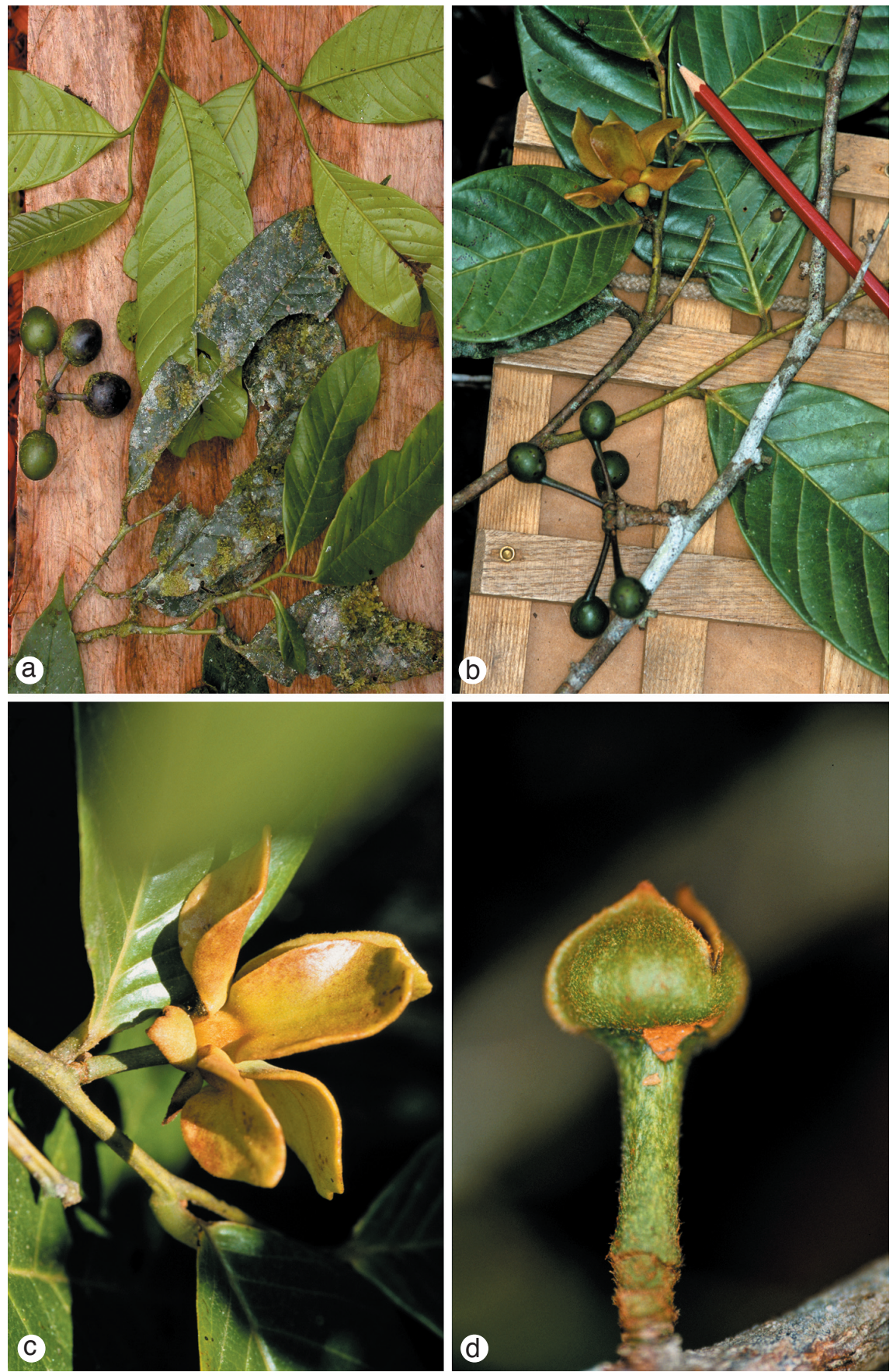

Plate 4. Guatteria asplundiana R.E.Fr. a. Twig and fruit; b. flowering and fruiting twig; c. flowering twig; d. flower bud (a: Homeier 1897; b-d: Pirie et al. 122). - Photos: a by J. Homeier; b-d by M.D. Pirie. 


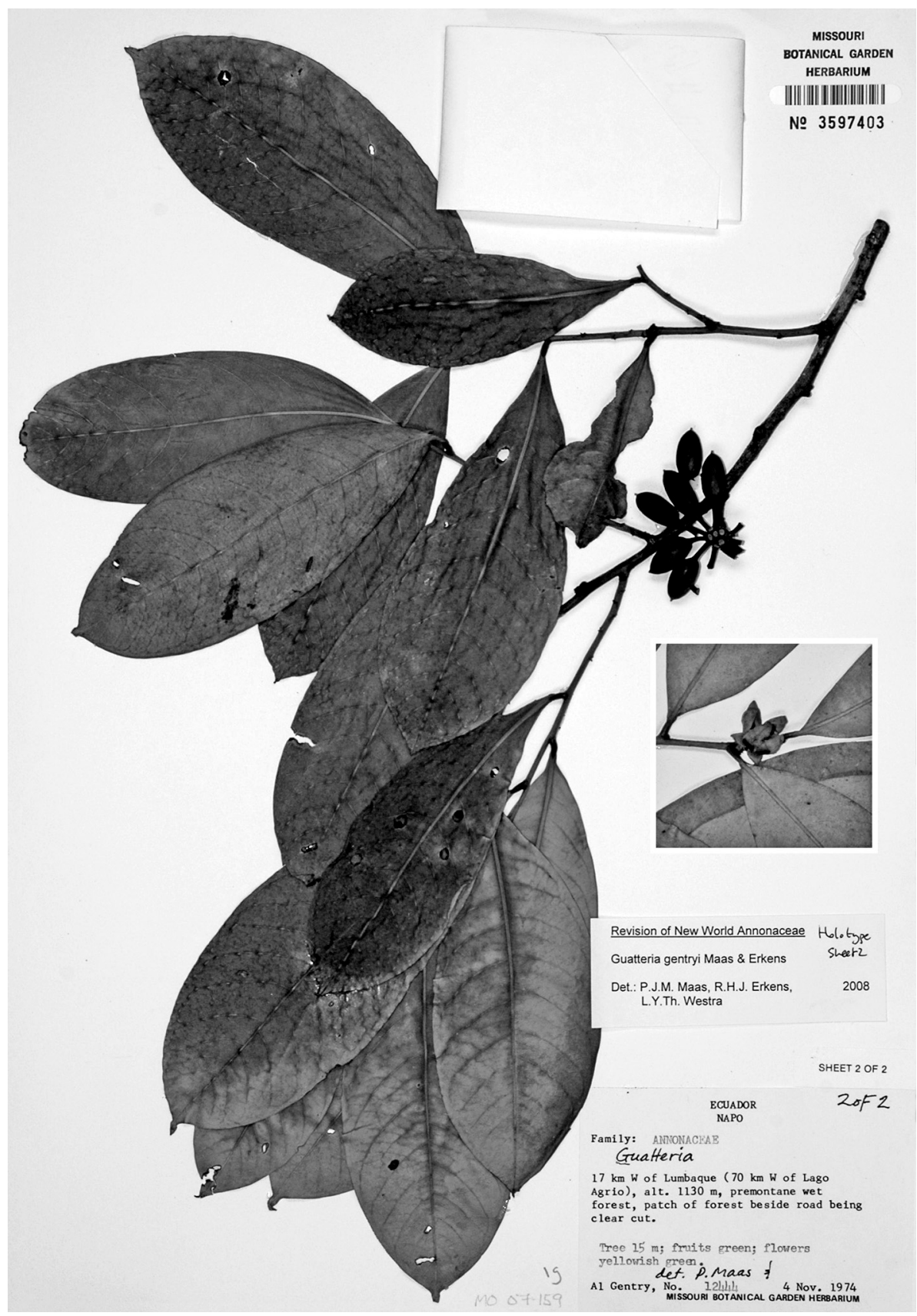

Fig. 10. Guatteria gentryi Maas \& Erkens. Fruiting twig; inset: flowering twig (Gentry 12444, holo part 2, MO; inset: idem, holo part 1, MO). 
Note - Guatteria fractiflexa is one of the two liana species in the genus, the other being G. scandens, a species quite common in the Guianas. Guatteria fractiflexa is quite remarkable by the zigzag branches (hence the specific epithet).

Selected other specimen examined:

PERU. Amazonas: Distr. Bagua, Imaza, Tayu Mujaji, 900-1030 m, 17 February 2002, Vásquez 27596 (MO, U).

\section{Guatteria gentryi Maas \& Erkens, spec. nov. - Fig. 10; Plate 3; Map 3}

Species foliis costa supra elevata ab omnibus speciebus Guatteriae Aequatoriam incolentibus divergens. - Typus: Gentry 12444 (holo MO, 2 sheets; iso U), Ecuador, Sucumbíos, 17 km W of Lumbaque (70 km W of Lago Agrio), 1130 m, 4 November 1974.

Guatteria sp. 8 Chatrou et al. (1997) 110.

Tree 5-20 m tall, 10-40 cm diam.; young twigs sparsely covered with appressed hairs, very soon glabrous. Leaves: petiole 6-12 $\mathrm{mm}$ long, 2-3 mm diam.; lamina narrowly elliptic, $14-25$ by $4-8 \mathrm{~cm}$ (leaf index $2.8-4$ ), chartaceous, not verruculose, dull, greenish brown above, not or sometimes slightly verruculose below, brownish below, glabrous above, rather densely covered with appressed hairs in the youngest stages but very soon becoming almost completely glabrous below, base acute to obtuse, apex acuminate (acumen 5-15 mm long, its apex obtuse), primary vein slightly raised above, secondary veins distinct, 10-13 on either side of primary vein, prominent above, smallest distance between loops and margin 2-3 $\mathrm{mm}$. Flowers in axils of leaves or on leafless branches, simple or in pairs; pedicels 4-8 $\mathrm{mm}$ long, 1.5-2 mm diam., fruiting pedicels 5-10 $\mathrm{mm}$ long, 3-4 $\mathrm{mm}$ diam., densely covered with appressed hairs, articulated at 2/3-1/2 from the base, bracts 3-5 below the articulation; flower buds broadly ovoid; sepals free or basally connate, broadly ovate, $5-6$ by $5 \mathrm{~mm}$, appressed to patent, outer side densely covered with appressed hairs; petals green, maturing dull yellow, yellow to cream in vivo, subequal, ovate, elliptic to oblong-ovate, $12-20$ by 6-9 mm, outer side densely covered with appressed hairs; stamens $1.5-2 \mathrm{~mm}$ long, connective shield finely papillate-hairy. Monocarps 10-30, green to finally black in vivo, black, rarely brown in sicco, ellipsoid, $15-20$ by $8-14 \mathrm{~mm}$, rather densely covered with appressed hairs, very soon becoming glabrous, apex apiculate (apiculum up to $1 \mathrm{~mm}$ long), wall $0.2-2 \mathrm{~mm}$ thick, stipes $7-18$ by 1-2 mm. Seed ellipsoid, 15-16 by $8-10 \mathrm{~mm}$, brown, strongly rugose.

Distribution - Amazonian Ecuador and Peru.

Habitat \& Ecology - In non-inundated, primary, sometimes premontane, wet forest, on clayey, red soil. At elevations of 300-1300 m. Flowering: March to May and September to November; fruiting: throughout the year.

Vernacular name - Ecuador: Cara huasca (Quichua).

Notes - Guatteria gentryi has been named after our friend and dear colleague, the late Alwyn ('Al') Gentry, one of the greatest Neotropical taxonomists of the last century.

The species can be recognized at first glance by its primary vein which is slightly raised on the upper side of the lamina, a feature not met within any other species of Guatteria in Ecuador. Further noteworthy aspects are the strongly furrowed and ridged seeds, which makes them resemble miniature brains. The flowers and fruits are very shortly pedicellate. 


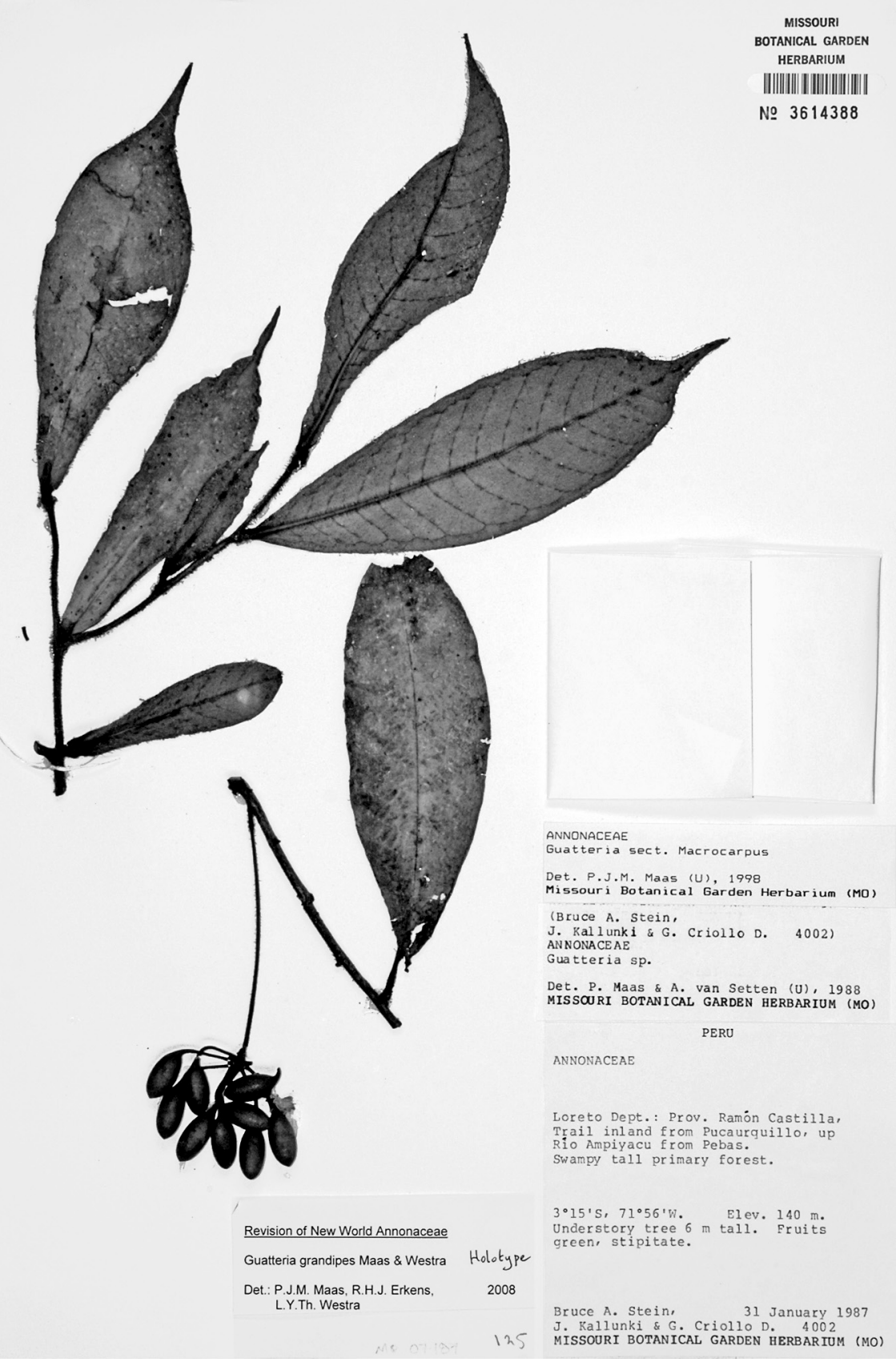

Fig. 11. Guatteria grandipes Maas \& Westra. Fruiting twig (Stein et al. 4002, holo MO). 
Selection of other specimens examined:

ECUADOR. Napo: Cantón Tena, Estación Biológica Jatun Sacha, Río Napo, 8 km E of Misahuallí, 400 m, 14 April 1991, Palacios 7075 (MO, U). Pastaza: Via Auca, 115 km S of Coca, near Río Tiguino, 320 m, 26-31 January 1989, Neill \& Hurtado 8858 (MO, U). Sucumbíos: Cantón Gonzalo Pizarro, $6 \mathrm{~km}$ N of Campo Bermejo, $30 \mathrm{~km}$ NW of Lago Agrio, 1050 m, 23 March 1990, Cerón et al. 9096 (U).

PERU. Amazonas: Prov. Bagua, Distr. Imaza, Kampaensa, above Río Shimutaz, 450 m, 20 October 1995, Rodriguez et al. 578 (U); Prov. Bagua, Distr. Imaza, Kampaensa, 320 m, Vásquez et al. 24433 (MO, U); Prov. Condorcanqui, Distr. Cenepa, Tutino, 340 m, 22 October 1995, Vásquez et al. 20391 $(\mathrm{MO}, \mathrm{U})$.

\section{Guatteria grandipes Maas \& Westra, spec. nov. - Fig. 11; Map 2}

Ab omnibus speciebus sectionis Mecocarpi pedicellis ad $90 \mathrm{~mm}$ longis bene differt. Typus: Stein et al. 4002 (holo MO; iso U), Peru, Loreto, Prov. Ramón Castilla, trail inland from Pucaurquillo, up Río Ampiyacu from Pebas, 140 m, 31 January 1987.

Tree or shrub 4-6 m tall; young twigs densely covered with erect, rough, brown hairs ('hirsute') 1.5-2.5 mm long. Leaves: petiole c. $5 \mathrm{~mm}$ long, 2-3 mm diam.; lamina narrowly obovate to narrowly elliptic, $16-23$ by $4-7 \mathrm{~cm}$ (leaf index 3.3-4), coriaceous, densely verruculose, dull, brown to greenish brown above, brown below, glabrous above, densely covered with erect, rough, brown hairs ('hirsute') $1.5-2.5 \mathrm{~mm}$ long below, base narrowly acute, apex acuminate (acumen $5-15 \mathrm{~mm}$ long), primary vein impressed above, secondary veins distinct, $15-25$ on either side of primary vein, impressed to flat above, marginal vein present, smallest distance between marginal vein and margin 2-3 mm. Flowers in leaf axils, solitary; pedicels 70-90 mm long, $1 \mathrm{~mm}$ diam., densely to rather densely covered with erect, rough, brown hairs ('hirsute') 1.5-2.5 mm long, articulated at c. $5 \mathrm{~mm}$ from the base, bracts not seen; flower buds subglobose; sepals free, ovate, 11-12 by $6 \mathrm{~mm}$, appressed, outer side densely covered with appressed, white hairs; petals greenish cream in vivo, subequal, young ones ovate, c. 14 by $8 \mathrm{~mm}$, outer side densely covered with appressed, white hairs; stamens c. $2 \mathrm{~mm}$ long, connective shield densely papillate. Monocarps c. 15, green in vivo, brown in sicco, ellipsoid, $15-16$ by $7 \mathrm{~mm}$, rather densely covered with erect hairs, apex apiculate (apiculum $<0.2 \mathrm{~mm}$ long), wall $0.2-0.3 \mathrm{~mm}$ thick, stipes $15-17$ by $1 \mathrm{~mm}$. Seed (young ones!) ellipsoid, c. 16 by $7 \mathrm{~mm}$, pale brown, rugose.

Distribution - Amazonian Peru (Loreto).

Habitat \& Ecology - In forest (the type collection from 'swampy forest'), on lateritic soil. At elevations of 120-140 m. Flowering: August; fruiting: January.

Note - Guatteria grandipes belongs to Fries's section Mecocarpus by its verruculose leaves, provided with a marginal vein. It differs from all species of that section by its extremely long pedicels of up to $90 \mathrm{~mm}$ long!

Other specimen examined:

PERU. Loreto: Prov. Maynas, Distr. Las Amazonas, 'Roca Interna', 120-130 m, 15 August 1991, Grández \& Jaramillo 2788 (U).

\section{Guatteria japurensis Maas \& Westra, spec. nov. - Fig. 12; Map 1}

Species foliis rugulosis venis indistinctis, pedicellis longissimis distincta. - Typus: Amaral et al. 518 (holo U; iso NY), Brazil, Amazonas, right bank of Rio Japurá, Vila Bittencourt, Serrinha, 100 m, 16 November 1982. 


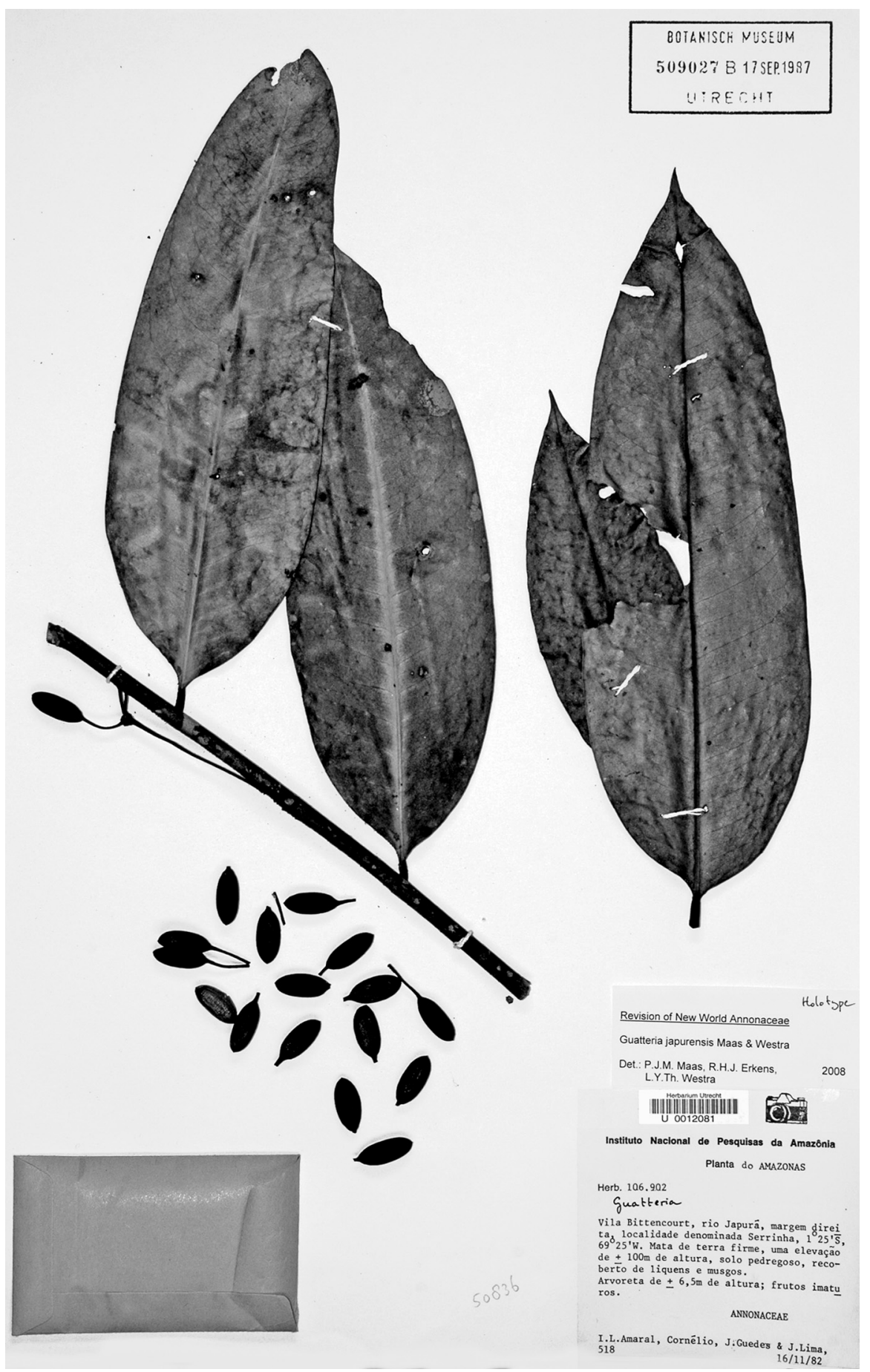

Fig. 12. Guatteria japurensis Maas \& Westra. Fruiting twig (Amaral et al. 518, holo U). 

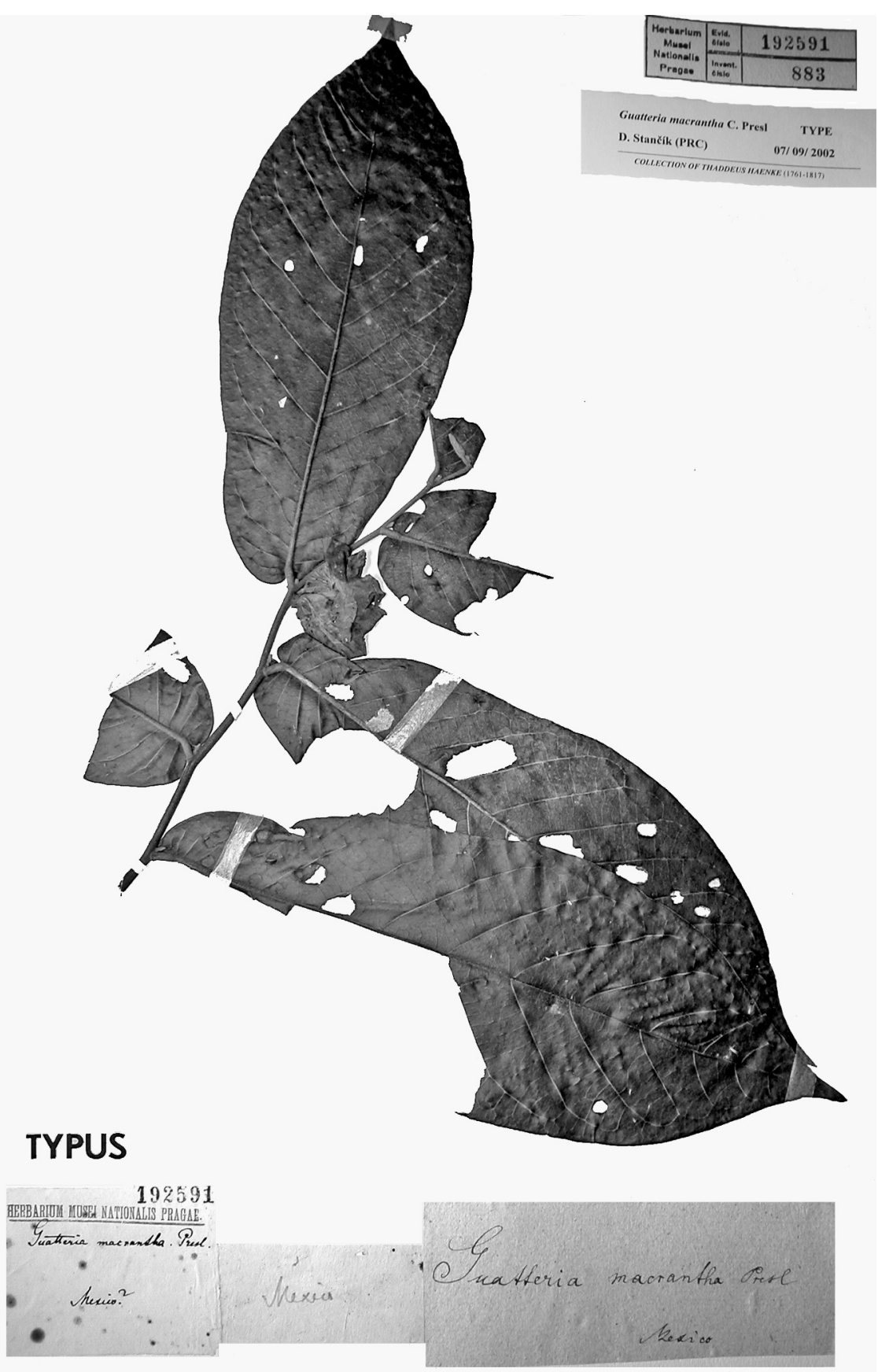

Fig. 13. Guatteria macrantha C.Presl. Flowering twig (Haenke s.n., holo PR). 


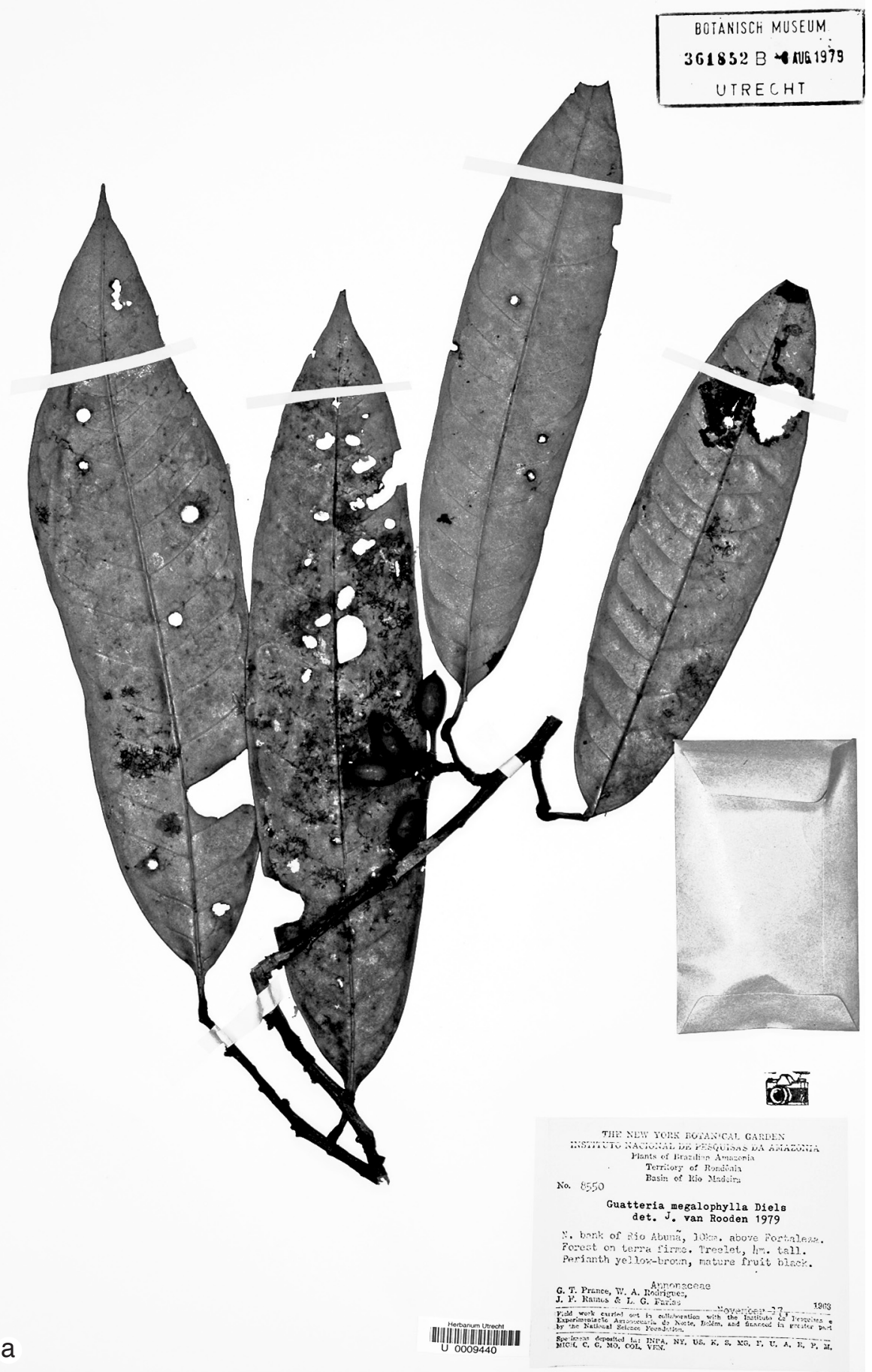




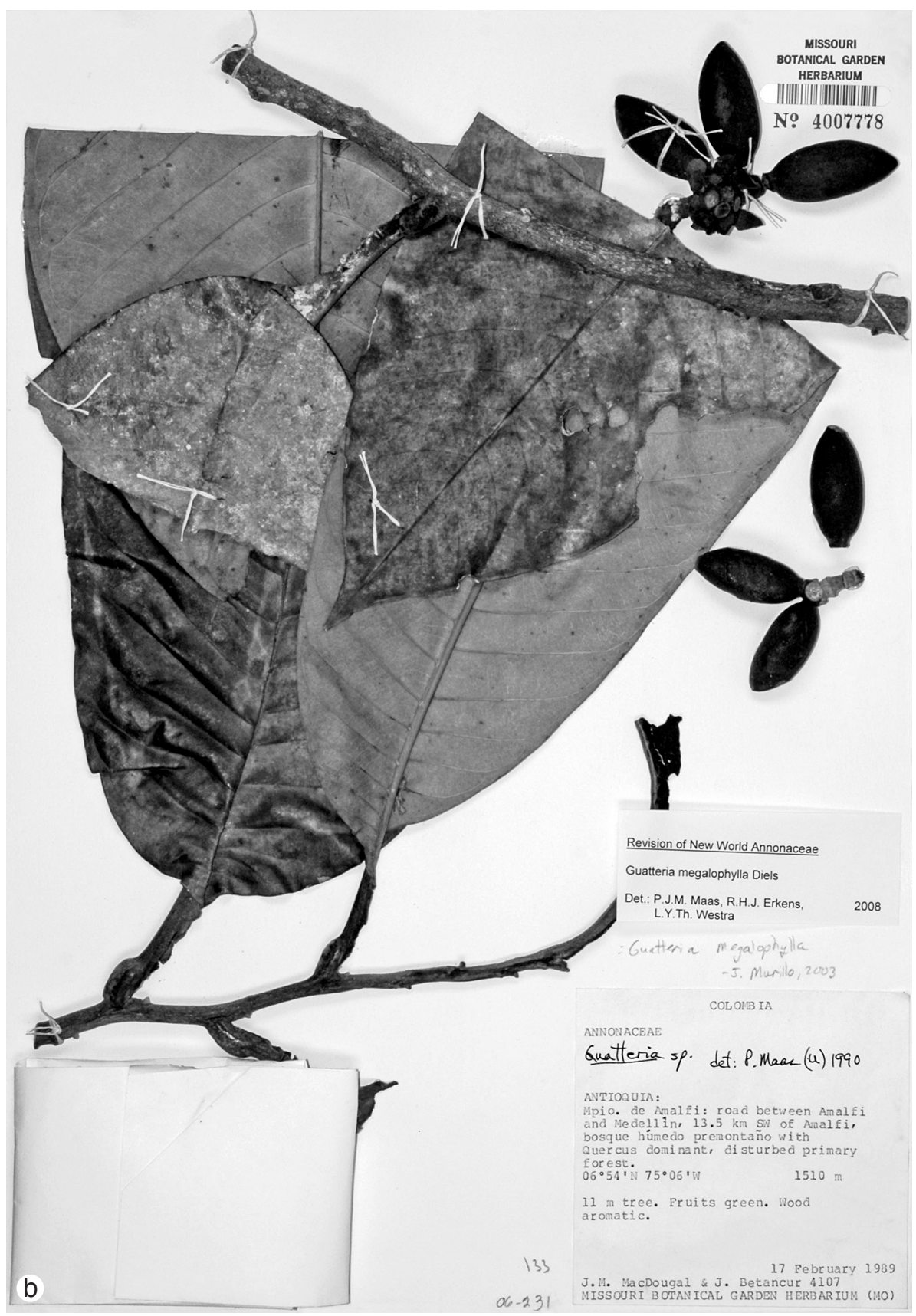

\section{$\uparrow$}

Fig. 14. Guatteria megalophylla Diels. a. Fruiting twig; b. fruiting twig with aberrant monocarps (a: Prance et al. 8550, U; b: MacDougal \& Betancur 4107, MO). 
Small tree c. $6.5 \mathrm{~m}$ tall; twigs (no growth tip seen) glabrous. Leaves: petiole c. $10 \mathrm{~mm}$ long, 3-4 mm diam.; lamina narrowly elliptic-ovate, $16-27$ by $5-8.5 \mathrm{~cm}$ (index $3-4$ ), chartaceous to thinly coriaceous, rugulose above, not or sparsely verruculose along primary vein only, slightly shiny and brownish green above, dull brownish green below, glabrous on both sides, base shortly attenuate, apex acuminate (acumen c. $10 \mathrm{~mm}$ long), primary vein flat above, secondary veins weakly distinct, $15-18$ on either side of primary vein, prominent above, smallest distance between loops and margin 1-2 mm. Flowers among leaves or on older branches, in 1-several-flowered inflorescences, only seen in fruiting stage: fruiting pedicels $50-60 \mathrm{~mm}$ long, $1-1.5 \mathrm{~mm}$ diam, glabrous to sparsely covered with appressed hairs, articulated at c. 1/10 from the base; flower buds, sepals, petals, and stamens not seen. Monocarps 10-15, immature, blackish brown in sicco, ellipsoid to narrowly ellipsoid, $17-20$ by $7-8 \mathrm{~mm}$, glabrous, apex apiculate (apiculum $0.2-0.4 \mathrm{~mm}$ long), wall c. $0.2 \mathrm{~mm}$ thick, stipes $11-17$ by $1-1.5 \mathrm{~mm}$. Seed narrowly ellipsoid, c. 18 by $7 \mathrm{~mm}$, brown, shiny, slightly rugose.

Distribution - Western Amazonian Brazil (Amazonas).

Habitat \& Ecology - In non-inundated forest, on stony soil covered with lichens and mosses. At elevations of c. 100 m. Flowering: unknown; fruiting: November.

Note - Guatteria japurensis is most distinctive by the long and slender fruiting pedicels, which are very unusual in Guatteria. Another noteworthy feature is found in its leaves which are indistinctly veined and which are rugulose on the upper surface.

\section{Guatteria macrantha C.Presl - Fig. 13}

Guatteria macrantha C.Presl (1835) 78. - Type: Haenke s.n. (holo PR), locality unknown.

Guatteria macrantha has been described by Presl (1835) as having stellate hairs and inflorescences opposite the leaves. These characteristics are not found in any species of Guatteria. Although the monocarps are unknown and the locality is uncertain ('habitat in Mexico?'), the specimen can be identified as Uvaria (pers. comm. P. Keßler). Uvaria does not occur in Mexico, but this collection was probably made somewhere else. It is known that many of Haenke's labels containing the locality information have become misplaced, and that the localities given by Presl can, therefore, not always be trusted (Stearn 1938). For instance, species now known to be exclusively American are recorded by Presl from the Philippines, and vice versa.

\section{Guatteria megalophylla Diels - Fig. 14; Map 4}

Guatteria megalophylla Diels (1905) 127.

Guatteria megalophylla is a species widespread all over Amazonian America (Colombia, Ecuador, Peru, Brazil) and in Guyana, at low elevations up to $600 \mathrm{~m}$. It is easily recognizable by its very large leaves (of up to 75 by $20 \mathrm{~cm}$ !) with a very distinct and impressed marginal vein, rather long petioles, shortly pedicellate flowers (mostly produced from leafless branches) and shortly stipitate monocarps.

Some specimens from the Colombian state of Antioquia (occurring in premontane Quercus forests of the Colombian Cordillera Central, Fig. 14b) have monocarps and seeds which are extremely large for a species of Guatteria, namely monocarps 30-40 mm long, seeds c. $30 \mathrm{~mm}$ long, whereas the monocarps are almost sessile (stipe c. $1 \mathrm{~mm}$ 
long). However, as all 'essential' characters of the leaves (a.o. the impressed marginal vein) fit in with G. megalophylla we consider it to be an extreme form of that species.

Specimens examined:

Colombia. Antioquia: Mun. Amalfi, 10-13 km from Amalfi, near Medellín, Cordillera Central, 1590-1650 m, 29 September 1988, Betancur et al. 854 (MO, U); Mun. Amalfi, road Amalfi-Medellín, 13.5 km SW of Amalfi, 1510 m, 17 February 1989, MacDougal \& Betancur 4107 (MO, U).

\section{Guatteria microcarpa Ruiz \& Pav. ex G.Don - Fig. 15; Map 4}

Guatteria microcarpa Ruiz \& Pav. ex G.Don (1831) 100. - Type: Ruiz s.n. (holo B), Ecuador, Guayas, Guayaquil ('Huayaquil'), anno 1800.

Guatteria sp. 15 Chatrou et al. (1997) 112.

Tree or shrub $2-8(-14) \mathrm{m}$ tall, to c. $10 \mathrm{~cm}$ diam.; young twigs densely to sparsely covered with erect, brown hairs, soon glabrous. Leaves: petiole 3-6 mm long, 1-2 mm diam.; lamina narrowly elliptic to narrowly obovate, $10-22$ by (3-)5-10 cm (leaf index 2-3.6), chartaceous, not verruculose, somewhat shiny, dark green, greyish green or greyish brown above, pale to dark brown below, sparsely covered with appressed and erect hairs, particularly along primary and secondary veins above, rather densely to sparsely covered with erect, brown hairs below, base obtuse, sometimes acute, apex acuminate (acumen 5-20 mm long), primary vein impressed above, secondary veins distinct, 10-15 on either side of primary vein, impressed or sometimes flat above, smallest distance between loops and margin 2-5 mm. Flowers in leaf axils or on older branchlets, solitary (exceptionally in 2- or 3-flowered inflorescences); pedicels 20-50 $\mathrm{mm}$ long, 0.5-2 mm diam., fruiting pedicels to $65 \mathrm{~mm}$ long, $3 \mathrm{~mm}$ diam., densely covered with erect hairs, becoming glabrous in age or not, articulated at $1 / 5-1 / 3$ from the base, with ( 1 or) 2 bracts below articulation and few bracts at the base, bracts minute, to c. 4 by $2 \mathrm{~mm}$; flower buds broadly ovoid; sepals free to basally connate, broadly

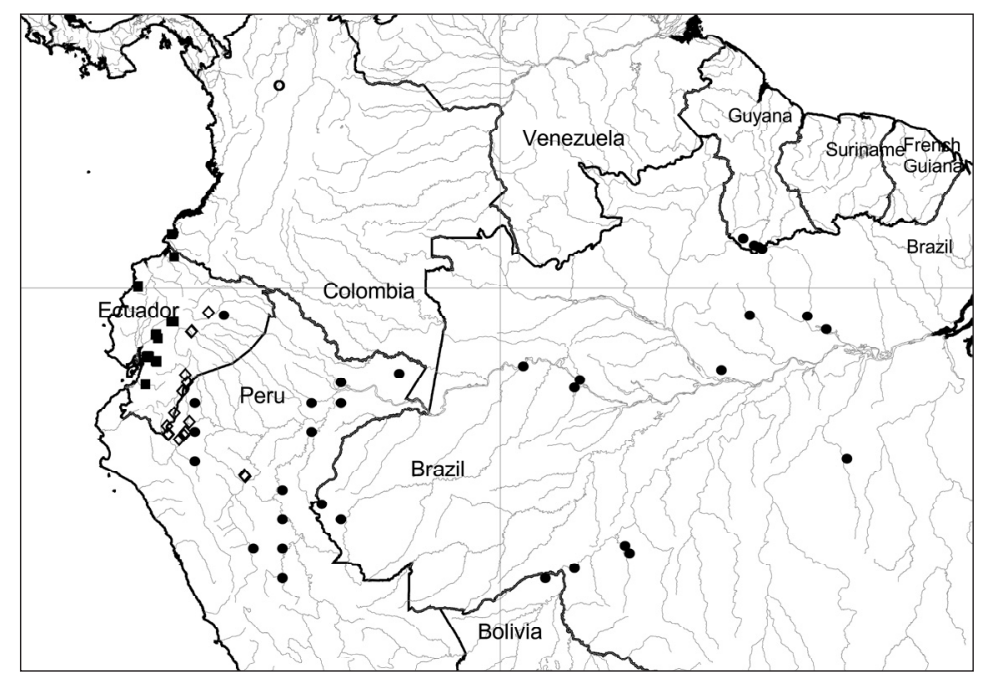

Map 4. Distribution of Guatteria megalophylla Diels (@; big fruited specimens indicated by $\bigcirc$ ), G. microcarpa Ruiz \& Pav. (ם), G. pastazae R.E.Fr $(\diamond)$. 


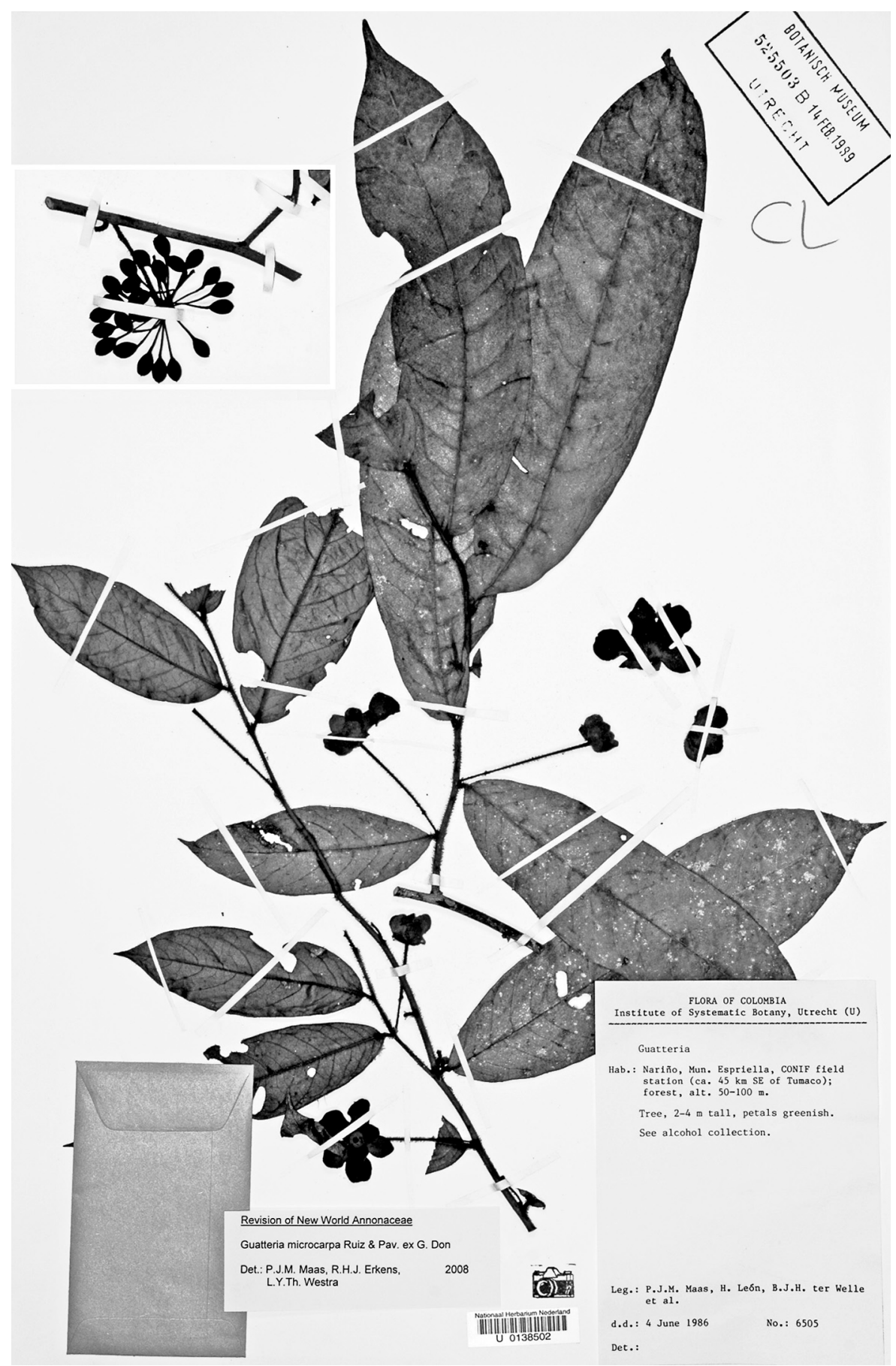

Fig. 15. Guatteria microcarpa Ruiz \& Pav. ex G.Don. Flowering twig; inset: fruiting twig (Maas et al. 6505, U; inset: Palacios 2596, U). 
ovate, $5-7\{-9)$ by $5-7\{-9) \mathrm{mm}$, appressed to patent, outer side densely covered with appressed hairs; petals green, maturing cream in vivo, unequal, elliptic-obovate to obovate-oblong, outer ones $12-20$ by $8-10 \mathrm{~mm}$, inner ones $17-23$ by $11-12 \mathrm{~mm}$, outer side of outer petals densely covered with appressed hairs; stamens 1.5-2 mm long, connective finely papillate-hairy. Monocarps 30-50, dark green, maturing black to purple-black in vivo, black in sicco, ellipsoid, $8-10$ by $5-6 \mathrm{~mm}$, glabrous, except for some scattered, appressed hairs, particularly at the apex, apex apiculate (apiculum $<0.5 \mathrm{~mm}$ long), wall $0.2-0.3 \mathrm{~mm}$ thick, stipes red to purple, $12-25$ by $1 \mathrm{~mm}$. Seed ellipsoid, $8-9$ by $5-6 \mathrm{~mm}$, pale to dark brown, slightly foveolate.

Distribution - Western Ecuador and adjacent Colombia (Nariño).

Habitat \& Ecology - In non-inundated, primary or secondary forest ('bosque húmedo tropical' or 'bosque muy húmedo premontano'). At elevations of 0-1000 m. Flowering and fruiting: throughout the year.

Vernacular name - Ecuador: Punta de lanza.

Note - Guatteria microcarpa, a species belonging to Fries's section Trichoclonia, is recognizable by leaves with secondary veins mostly impressed on the upper side, and by relatively long and slender pedicels.

Selection of other specimens examined:

COLOMBIA. Nariño: Mun. Espriella, CONIF Field Station, c. $45 \mathrm{~km}$ SE of Tumaco, 50-100 m, 4 June 1986, Maas et al. 6504, 6505 (U).

ECUADOR. Cañar: $20 \mathrm{~km}$ SE of La Troncal, km 6 of road from Manta Real to Caimatán, 28 May 2005, Vargas \& Defas 5685 (U). Esmeraldas: San Lorenzo, Estación Experimental La Chiquita, 70 m, 4 July 1990, Palacios 5205 (MO, U). Los Ríos: Hacienda Clementina, Cerro Samama, Puerta Negra, 150 m, 9 October 2003, Ståhl \& Cornejo 6166 (U). Manabí: Cantón Pedernales, Bosque Protector Cerro Pata de Pájaro, E of Pedernales, 400-700 m, 8 March 1997, Vargas et al. 1249 (U).

\section{Guatteria pastazae R.E.Fr. - Fig. 16; Plate 1; Map 4}

Guatteria pastazae R.E.Fr. (1947) 5, t. 2. - Type: Lugo 181 (holo S; iso US), Ecuador, Pastaza, Mera, elevation not recorded, 4 April 1940.

Tree 4-28 m tall; young twigs densely to sparsely covered with appressed hairs, soon glabrous. Leaves: petiole 3-10 $\mathrm{mm}$ long, 2-3 mm diam.; lamina narrowly oblongelliptic to narrowly oblong-obovate, $10-27$ by $3-8 \mathrm{~cm}$ (leaf index $2.5-4.6$ ), coriaceous to chartaceous, rather densely to sparsely verruculose, greyish green, greyish brown, or brown above, pale to dark brown below, glabrous above except for some scattered hairs along primary and secondary veins above, sparsely covered with appressed hairs below, base attenuate, basal margins often somewhat rolled inwards, apex acuminate (acumen 10-15 mm long), primary vein impressed above, slightly keeled below, secondary veins rather indistinct, $12-15$ on either side of primary vein, slightly prominent above, smallest distance between loops and margin 1-5 mm. Flowers mostly in axils of leaves or on branchlets after leaf shedding, 1 (or 2); pedicels 3-15 mm long, 1-2.5 $\mathrm{mm}$ diam., fruiting pedicels to $25 \mathrm{~mm}$ long, to $3 \mathrm{~mm}$ diam., densely to rather densely covered with appressed, brown hairs, articulated at 1/4-1/3 from the base, with 5 or 6 bracts, c. 7 by $3 \mathrm{~mm}$ (only one seen), soon falling and leaving prominent scars on lower pedicel; flower buds ovoid; sepals basally connate to free, broadly elliptic-ovate, $5-10$ by $5-8 \mathrm{~mm}$, appressed, but soon becoming patent to finally reflexed, outer side densely covered with appressed, brown hairs; petals green to greenish yellow and 


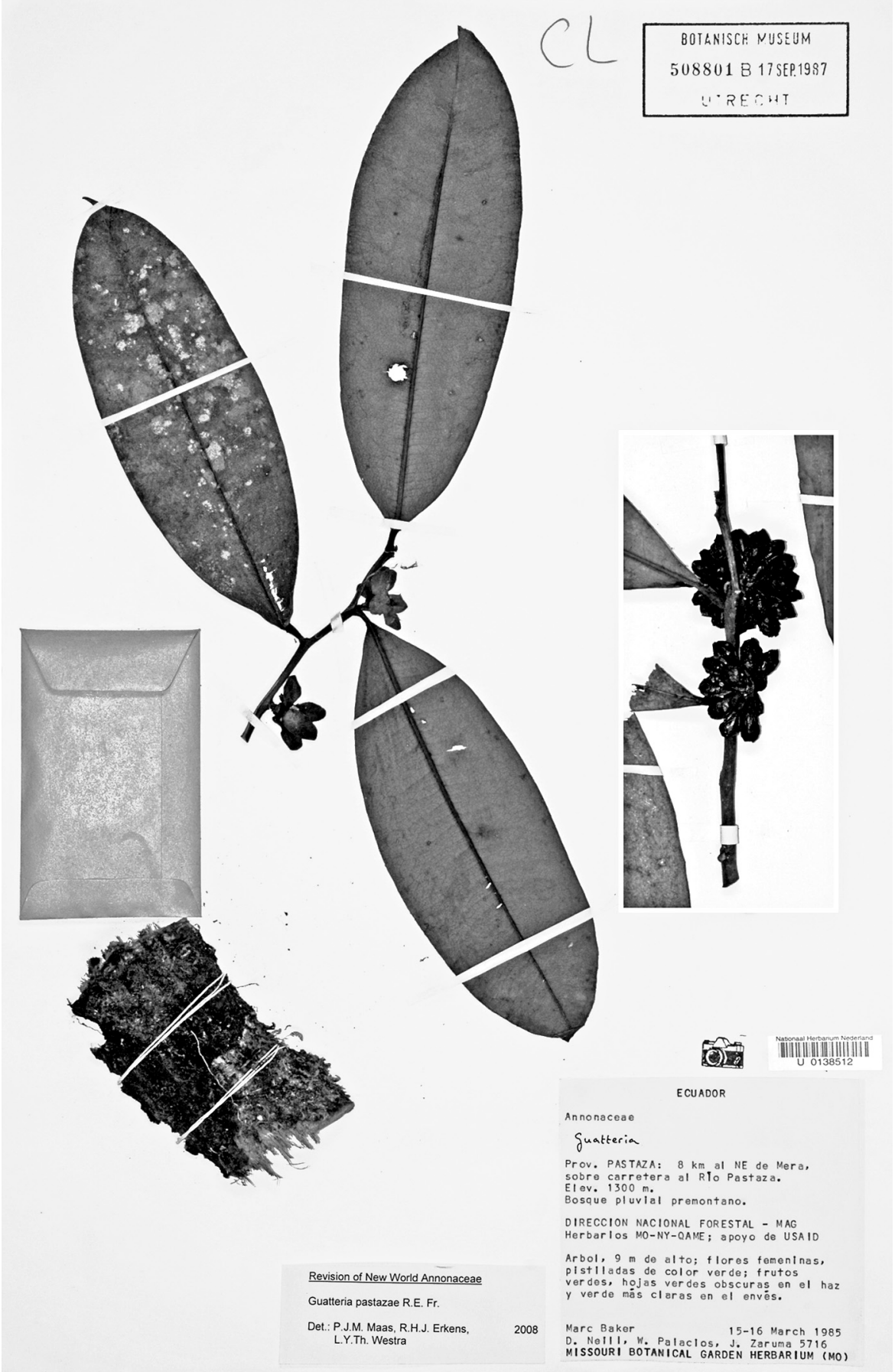

Fig. 16. Guatteria pastazae R.E.Fr. Flowering twig; inset: fruiting twig (Baker et al. 5716, U; inset: Van der Werff et al. 19221, U). 
slightly tinged with red in vivo, unequal, elliptic-oblong to elliptic-obovate, the outer ones $13-15\{-25\}$ by $6-7 \mathrm{~mm}$, the inner ones $18-20\{-28\}$ by $6-12 \mathrm{~mm}$, outer side densely covered with appressed hairs; stamens $1.5-2 \mathrm{~mm}$ long, connective shield finely papillate-hairy. Monocarps 10-30, green, maturing purple in vivo, black in sicco, ellipsoid, 11-14\{-20\} by $7-9\{-15\} \mathrm{mm}$, longitudinally wrinkled in sicco, sparsely covered with appressed hairs to glabrous, apex acute to apiculate (apiculum $<0.5 \mathrm{~mm}$ long), wall 0.5-1\{-4\} mm thick, stipes 1-3(-9) by 1.5-2 mm. Seed ellipsoid, 10-15 by $6-8 \mathrm{~mm}$, pale brown, slightly to strongly rugose (in sicco) to slightly foveolate (in vivo).

Distribution - Amazonian Ecuador and Peru.

Habitat \& Ecology - In premontane and montane forest, on soils derived from sandstone substrate or on red clay. At elevations of 300-1800(-2200) m. Flowering: from November to May; fruiting: from July to March.

Vernacular names - Peru: Palo yais, Wampu yais, Yais.

Notes - Guatteria pastazae was previously known from only 2 collections near Mera. It is well recognizable by its verruculose leaves with obscure venation and an attenuate leaf base, combined with shortly pedicellate flowers and shortly stipitate monocarps.

Guatteria pastazae shows some features of G. puncticulata R.E.Fr., a species occurring in the lowlands of Peru (Loreto) and Brazil (Amazonas), like the verruculose leaves and obscure leaf venation. It differs, however, by its much shorter stipes (stipes shorter than to almost equalling monocarp length) versus stipes longer than monocarp.

A specimen from Peru (Rodríguez R. \& Cruz A. 2053) might be placed near G. pastazae, but it differs by fruiting pedicels $20-25 \mathrm{~mm}$ long and an articulation at $1 / 5-1 / 4$ from the base, and by distinctly smaller leaves.

A specimen from Ecuador (Quizhpe et al. 1171) should be noted, too. It differs from $G$. pastazae by a fruiting pedicel $20 \mathrm{~mm}$ long and articulated about the middle. A very young floral bud shows an upper bract still in place, elliptic-ovate, c. $6 \mathrm{~mm}$ long, apex acute.

Selection of other specimens examined:

ECUADOR. Morona-Santiago: Cordillera del Condór, Centro Shuar Warints, Cerro Yukai Naint, 1200 m, 12 December 2002, Kajekai \& Grupo Shuar de Conservación 50 (MO, U). Pastaza: 8 km NE of Mera, Río Pastaza, 1300 m, 15-16 March 1985, Baker et al. 5716 (U). Zamora-Chinchipe: near mining camp at Río Tundaime, Río Quimi, 900-1000 m, 3 November 2004, Van der Werff et al. 19221 (MO, U).

Peru. Cajamarca: Prov. San Ignacio, San José de Lourdes, Jorge Chávez, 2000 m, 18 March 1997, Campos \& Corales 3557 (MO, U). San Martín: Prov. San Martín: km 20 to 35 of road from Tarapoto to Yurimaguas, 580 m, 7 December 2003, Pirie et al. 172 (U).

\section{Guatteria scalarinervia D.R.Simpson - Fig. 17; Plate 3; Map 1}

Guatteria scalarinervia D.R.Simpson (1975) 306. - Type: Reyna R., N. 40 (holo F; iso F, K, MAD, NY,

P, WIS), Peru, Loreto, Prov. Maynas, Distr. Santa María, Río Nanay, 150 m, 15 December 1967. Guatteria sp. 3 Chatrou et al. (1997) 109.

Cauliflorous tree 6-25 $\mathrm{m}$ tall, 5-25 cm diam.; young twigs rather densely covered with appressed hairs, soon glabrous. Leaves: petiole 15-20 mm long, 2-3 mm diam.; lamina narrowly elliptic, $13-18$ by $3.5-5 \mathrm{~cm}$ (leaf index $2.7-4$ ), chartaceous, not 

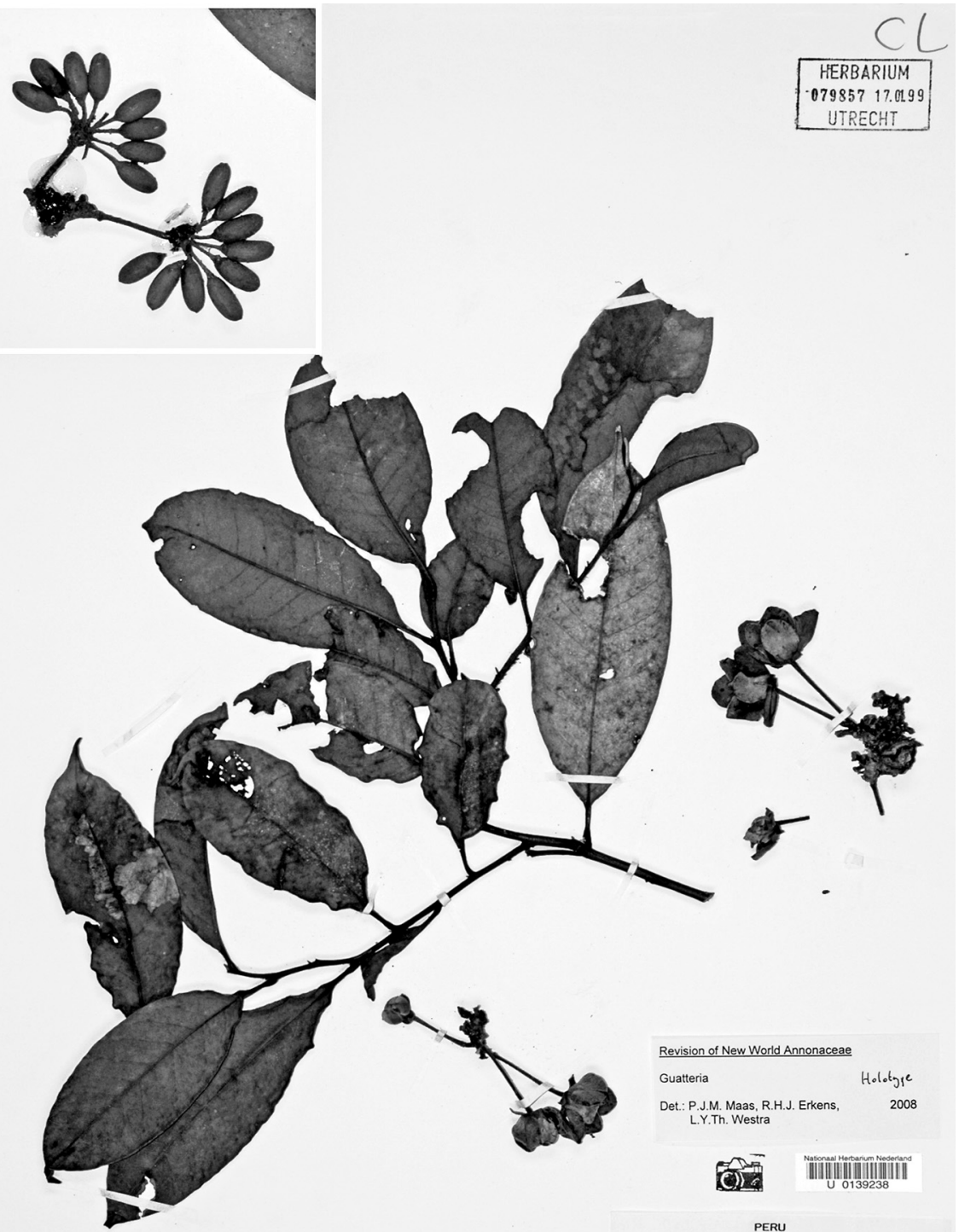

Det.: P.J.M. Maas, R.H.J. Erkens, 2008

$$
\text { 10. }
$$

PERU

ANNONACEAE
Guatteria

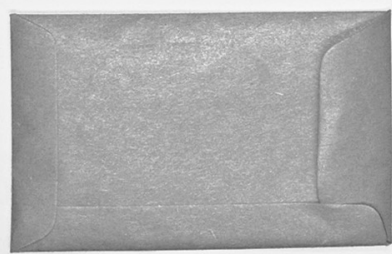

LORETO

Explornapo Tourist Camp, Quebrada

Sucusari, mature upland forest on sandy

$03^{\circ} 15$ 's $72 \cdot 55 \cdot w$

$130 \mathrm{~m}$

Tree $20 \mathrm{~m}$; flowers green turning

yellow, caulifiorous.

Al Gentry, R. Ortiz \& 7 June 1992 San Marcos Univ. M.s. course 77361

Fig. 17. Guatteria scalarinervia D.R.Simpson. Flowering twig; inset: infructescence (Gentry et al. 77361, holo U; inset: Revilla 2188, MO). 
verruculose, dull above, dark greenish brown above, pale brown below, glabrous above, rather densely covered with appressed hairs below, base acute to abruptly attenuate, apex acuminate (acumen 5-20 mm long), primary vein impressed above, secondary veins distinct, $10-15$ on either side of primary vein, impressed above, smallest distance between loops and margin 2-4 mm. Flowers in up to many-flowered clusters on the trunk; pedicels $20-35 \mathrm{~mm}$ long, $1-1.5 \mathrm{~mm}$ diam., fruiting pedicels to $40 \mathrm{~mm}$ long, to $2\{-3\} \mathrm{mm}$ diam., densely to sparsely covered with appressed hairs, articulated at $1 / 4-1 / 2$ from the base, bracts 2 below articulation, narrowly obtrullate to narrowly obovate-elliptic, $\{10-12$ by $4-5 \mathrm{~mm}\}$, lower part of pedicel with few bracts, broadly ovate, $\{$ c. 1 by $1 \mathrm{~mm}\}$, all bracts very soon falling off; flower buds broadly ovoid; sepals free, broadly ovate, 4-7 by 4-7 mm, appressed, outer side rather densely to densely covered with appressed hairs; petals green, maturing yellow to cream in vivo, equal, ovate, elliptic, to oblong-obovate, $12-14$ by $7-10 \mathrm{~mm}$, outer side densely covered with appressed hairs; stamens c. $1.5 \mathrm{~mm}$ long, connective shield glabrous. Monocarps 25-50, green, maturing bluish black to black in vivo, brownish in sicco, ellipsoid, $15-21$ by $7-11 \mathrm{~mm}$, rather densely to sparsely covered with appressed hairs, apex apiculate (apiculum to $1 \mathrm{~mm}$ long), wall $0.1-1 \mathrm{~mm}$ thick, stipes $10-25$ by $1 \mathrm{~mm}$. Seed ellipsoid, $15-18$ by $7-9 \mathrm{~mm}$, dark brown, rugose.

Distribution - Amazonian Ecuador (Orellana and Sucumbíos) and Peru (Loreto).

Habitat \& Ecology - In non-inundated forest (one collection from periodically inundated tahuampa forest), on red, clayey to lateritic soil. At elevations of 200-350 m. Flowering: April to June, and October; fruiting: January, May, and from August to November.

Vernacular name - Ecuador: Dimonkawe (Huaorani), Nagewe (Huaorani), Pungaracaspi, Pungaramuyo, Uñitawe (Huaorani).

Note - Guatteria scalarinervia is the only cauliflorous species of the genus known to occur in Ecuador so far. It is, moreover, recognized by relatively long petioles and stipes.

Selection of other specimens examined:

ECUADOR. Orellana: Cantón Orellana, Yasuní Forest Reserve, 200-300 m, 16 May 1996, Romoleroux et al. 2317 (U); Reserva Étnica Huaorani, Miwaguno, $140 \mathrm{~km} \mathrm{~S} \mathrm{of} \mathrm{Coca,} 250 \mathrm{~m}, 10$ May 2004, Naranjo \& Freire 370 (MO, U); Vía de los Zorros, 11 km W of Coca, left bank of Río Napo, 350 m, 7 August 1986, Zaruma 553 (MO, U). Sucumbíos: Reserva Faunistica Cuyabeno, N of Laguna Grande, 205-265 m, 13 May 1988, Renner 69066 (U).

PERU. Loreto: Explornapo Tourist Camp, Quebrada Sucusari, 120-200 m, 27 December 1998, Chatrou et al. $174(\mathrm{U})$.

\section{Guatteria venosa Erkens \& Maas, spec. nov. - Fig. 18; Map 1}

Species foliis venis secundariis pro ratione multis et supra impressis in venam marginalem manisfeste conjunctis facile distinguibilis. - Typus: T.D. Pennington et al. 15607 (holo U; iso K), Ecuador, Pichincha, Cantón Pedro Vicente Maldonado, Reserva Río Silanche, 600-700 m, November 1996.

Guatteria sp. 7 Chatrou et al. (1997) 110.

Tree (6-)10-24 m tall, 6-80 cm diam., with buttresses; young twigs glabrous, smooth or rather densely verruculose. Leaves: petiole 10-25 mm long, 3-5 mm diam.; lamina narrowly elliptic to narrowly obovate, $16-40$ by $6-15 \mathrm{~cm}$ (leaf index $2.6-3.6$ ), not 


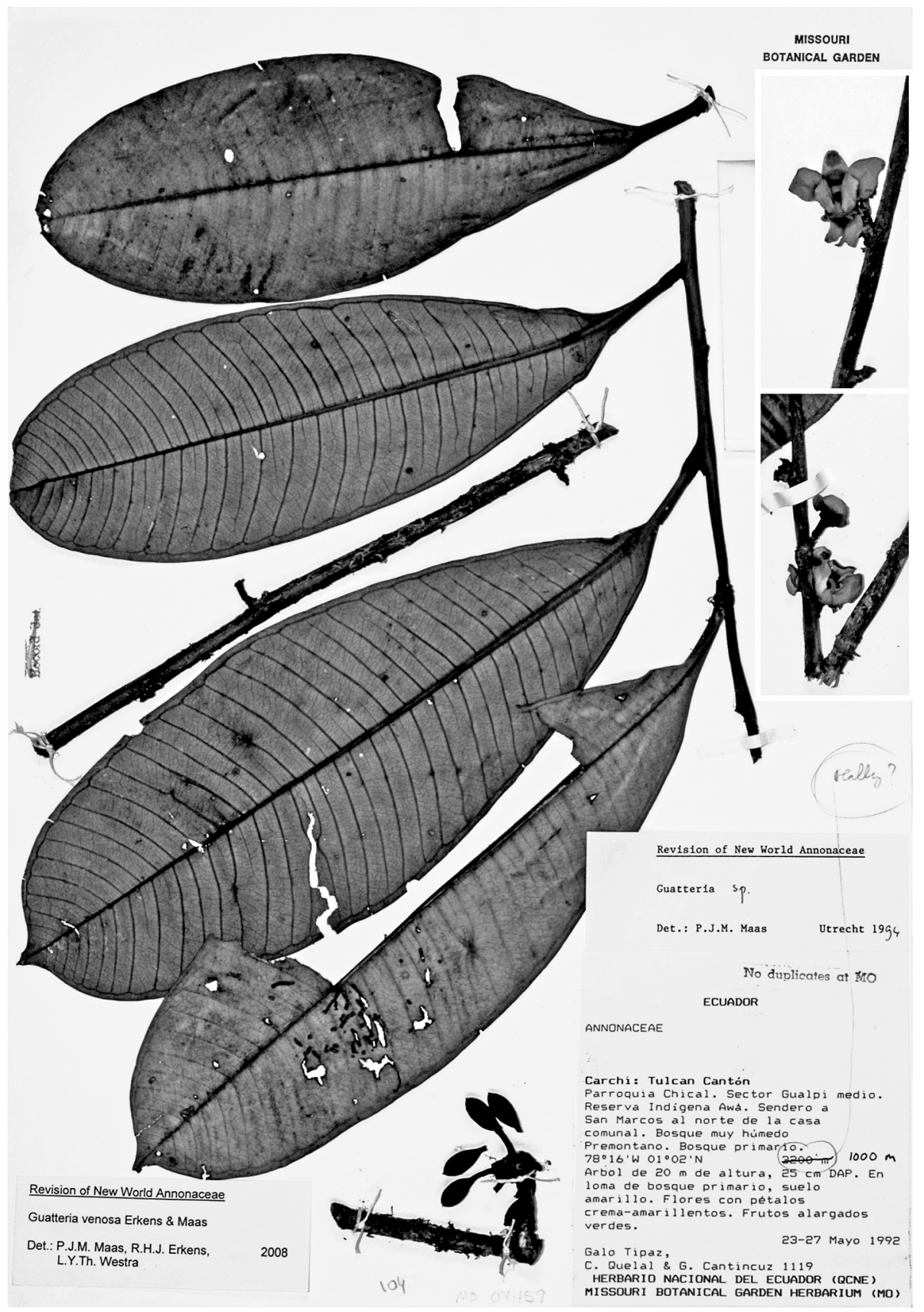

Fig. 18. Guatteria venosa Erkens \& Maas. Fruiting twig, inset top and bottom: flowering twig (Tipaz, et al. 1119, MO; inset top: T.D. Pennington et al. 15607, iso K; inset bottom: T.D. Pennington et al. 15607, holo U). 
verruculose or sparsely to rather densely verruculose toward the base, shiny above, greyish white above, pale brown below, glabrous above, sparsely covered with appressed hairs to glabrous below, base attenuate, apex acuminate (acumen 5-10 mm long), primary vein impressed above, rather densely to densely verruculose below toward the base, becoming sparsely verruculose to smooth toward the apex, secondary veins distinct, $25-35$ on either side of primary vein, strongly impressed above, marginal vein present, smallest distance between marginal vein and margin $2-5 \mathrm{~mm}$. Flowers mostly on older branchlets, or in axils of fallen leaves, in 2-several-flowered inflorescences or single (at least in fruit); pedicels 10-20 mm long, 1.5-2 mm diam., fruiting pedicels to $25 \mathrm{~mm}$ long, $5 \mathrm{~mm}$ diam., densely covered with appressed hairs, articulated at 1/6-1/3 from the base, with ( 1 or) 2 minute bracts immediately below articulation and $0-3$ bracts lower down; flower buds depressed ellipsoid to depressed ovoid; sepals basally connate to free, broadly ovate, $5-6$ by $5-6 \mathrm{~mm}$, appressed to patent, outer side densely covered with appressed hairs; petals green, greenish cream, tannish, to yellow in vivo, subequal, broadly ovate to broadly ovate-triangular, c. 10 by $10 \mathrm{~mm}$, outer side densely covered with appressed hairs; stamens c. $2 \mathrm{~mm}$ long, connective shield finely papillate-hairy to subglabrous. Monocarps 10-30, green, maturing black in vivo, black in sicco, ellipsoid, $11-14$ by $5-6 \mathrm{~mm}$, glabrous, except for some hairs at the apex, apex apiculate (apiculum c. $0.5 \mathrm{~mm}$ long), wall $0.5-0.8$ $\mathrm{mm}$ thick, stipes $5-9$ by $1.5-2 \mathrm{~mm}$. Seed ellipsoid, $10-13$ by $5-6 \mathrm{~mm}$, pale to dark brown, rugose.

Distribution - Western Ecuador (Carchi, Esmeraldas, Pichincha).

Habitat \& Ecology - In premontane wet forest. At elevations of 250-1000 m. Flowering: May, June, September to November; fruiting: February to June.

Vernacular name - Ecuador: Cargadera negra, Degteiug, Tilalde (Awapit).

Note - Guatteria venosa belongs to Fries's section Mecocarpus by its distinct marginal vein, the presence of verruculi on the leaves and by the short stipes. It is distinguished from other species of section Mecocarpus by an unusually high number of secondary veins (hence the specific name) and by the few verruculi on the leaves compared to other species in the section.

Selection of other specimens examined:

ECUADOR. Carchi: Maldonado, Parroquia Tobar Donoso, Reserva Etnica Awá, Sabalera, 6001000 m, 22 November 1992, Aulestia et al. 693 (MO, U); Cantón Tulcán, Parroquia Chical, Sector Gualpi Medio, Reserva Indigena Awá, road to San Marcos, 1000 m, 23 May 1992, Tipaz et al. 1119 (MO); border area between Carchi and Esmeraldas, $20 \mathrm{~km}$ past Lita on road Lita-Alto Tambo, $550 \mathrm{~m}$, 12 May 1991, Van der Werff et al. 12046 (MO, U). Esmeraldas: El Silencio, 250 m, 8 September 1998, Bonifaz \& Cornejo 3832 (U); Lita-San Lorenzo road, 10-20 km NW of Lita, 800 m, 12 May 1991, Gentry et al. 70116 (MO, U). Pichincha: Cantón Pedro Vicente Maldonado, Reserva Río Silanche, 600-700 m, November 1996, T.D. Pennington et al. 15384 (K, U).

\section{ACKNOWLEDGEMENTS}

We thank Rob Bakker for photographing herbarium specimens and Lars Chatrou (WAG), Philip Silverstone-Sopkin (CUVC), Michael Pirie (Z), Jürgen Homeier (GOET), and Marleen Botermans and Robin van Velzen (WAG) for providing photographs of their collections. Furthermore, we are grateful to the herbaria CUVC, GOET, K, MAD, MO, NY, and WIS for sending material on loan. Lastly, we like to thank Frits Adema and Lars Chatrou for critical reading and suggesting improvements on the manuscript. 


\section{REFERENCES}

Aublet, F. 1775. Histoire des plantes de la Guiane françoise. Pierre-François Dodot jeune, London, Paris.

Chatrou, L.W., P.J.M. Maas, C.P. Repetur \& H. Rainer. 1997. Preliminary list of Ecuadorean Annonaceae. In: R. Valencia \& H. Balslev (eds.), Estudios sobre diversidad y ecología de plantas, Memorias del II Congreso Ecuatoriano de Botánica: 97-122. Pontificia Universidad Católica del Ecuador, Quito.

De Saint-Hilaire, A.F.C.P. 1824-1825. Flora Brasiliae meridionalis. Apud A. Belin, Paris.

Diels, L. 1905. Anonaceae. In: R. Pilger, Beiträge zur Flora des Hylaea nach den Sammlungen von E. Ule. Verh. Bot. Vereins Prov. Brandenburg 47: 125-136; pl. 1.

Diels, L. 1906. Anonaceae. In: I. Urban, Plantae novae andinae imprimis Weberbauerianae. I. 9. Annonaceae andinae. Bot. Jahrb. Syst. 37: 408-410.

Diels, L. 1924a. Anonaceae. In: J. Mildbread, Plantae Tessmannianae peruvianae 1. Notizbl. Bot. Gart. Berlin-Dahlem 9: 137-141.

Diels, L. 1924b. Vermischte Diagnosen I. Notizbl. Bot. Gart. Berlin-Dahlem 9: 51-52.

Diels, L. 1927. Annonaceae II. In: J. Mildbread, Plantae Tessmannianae peruvianae 6. Notizbl. Bot. Gart. Berlin-Dahlem 10: 76-77.

Diels, L. 1931. Annonaceae novae. Notizbl. Bot. Gart. Berlin-Dahlem 11: 73-86.

Don, G. 1831. A general history of the dichlamydeous plants 1: 86-101. J.G. \& F. Rivington et al., London.

Dunal, M.F. 1817. Monographie de la famille des Anonacées. Treuttel \& Würtz, Paris.

Erkens, R.H.J. 2007. From morphological nightmare to molecular conundrum. Phylogenetic, evolutionary and taxonomic studies on Guatteria (Annonaceae). PhD-thesis, Utrecht University, Utrecht, The Netherlands (electronically available at: http://igitur-archive.library.uu.nl/dissertations/2007-0227-200317/UUindex.html).

Erkens, R.H.J., L.W. Chatrou, J. Koek-Noorman, J.W. Maas \& P.J.M. Maas. 2007a. Classification of a large and widespread genus of Neotropical trees, Guatteria (Annonaceae) and its three satellite genera Guatteriella, Guatteriopsis and Heteropetalum. Taxon 56: 757-774.

Erkens, R.H.J., L.W. Chatrou, J.W. Maas, T. van der Niet \& V. Savolainen. 2007b. A rapid diversification of rainforest trees (Guatteria; Annonaceae) following dispersal from Central into South America. Molec. Phylogenet. Evol. 44: 399-411.

Erkens, R.H.J. \& P.J.M. Maas. 2008. The Guatteria group disentangled: sinking Guatteriopsis, Guatteriella, and Heteropetalum into Guatteria. Rodriguésia 59: 401-406.

Erkens, R.H.J., P.J.M. Maas, L.W. Chatrou, G.E. Schatz \& N. Zamora. 2006. Seven taxonomic discoveries in Annonaceae from southeastern Central America. Blumea 51: 199-220.

Fries, R.E. 1938. Annonaceae. In: J.F. Macbride, Flora of Peru. Field Mus. Nat. Hist., Bot ser. 13, 2: $700-766$.

Fries, R.E. 1939. Revision der Arten einiger Annonaceen-Gattungen V. Acta Horti Berg. 12: 289577.

Fries, R.E. 1947. Die Annonaceen der vierten Regnellschen Expedition. Ark. Bot. 33A: 1-20.

Fries, R.E. 1948a. Contributions to the flora of tropical America XLVII. Annonaceae new to British Guiana. Kew Bull.: 229-235.

Fries, R.E. 1948b. New or noteworthy Annonaceae from tropical America. Kongl. Svenska Vetensk. Acad. Handl., ser. 3, 24: 3-19.

Fries, R.E. 1950. Contributions to the knowledge of the Annonaceae in northern South America. Ark. Bot. n.s., 1: 329-331.

Fries, R.E. 1952. Contributions to the flora of tropical America LIV. New trees and shrubs from British Guiana. Kew Bull.: 255-257.

Fries, R.E. 1955. Verstreute Beobachtungen hinsichtlich der Familie Annonaceae. Ark. Bot. n.s., 3: $35-42$.

Fries, R.E. 1956. Some new contributions to the knowledge of the Annonaceae in Colombia and Mexico. Ark. Bot. n.s., 3: 433-437.

Fries, R.E. 1957a. New species of Annonaceae from the Upper Amazon Basin. Ark. Bot. n.s., 3: 599-606. 
Fries, R.E. 1957b. Annonaceae. In: R.S. Cowan \& collaborators - New species and new records of plants in Guiana. Brittonia 8: 231-245.

Fries, R.E. 1959a. Die Annonaceen der sechsten Regnellschen Expedition. Ark. Bot. n.s., 4: 23-27.

Fries, R.E. 1959b. Annonaceae. In: H. Melchior (ed.), Die natürlichen Pflanzenfamilien, ed. 2, Band 17a II: 1-171. Duncker \& Humblot, Berlin.

Hutchinson, J. 1923. Contributions towards a phylogenetic classification of flowering plants II. The genera of Annonaceae. Bull. Misc. Inform. Kew: 241-261.

Maas, P.J.M., E.A. Mennega \& L.Y.Th. Westra. 1994. Studies in Annonaceae XXI. Index to species and infraspecific taxa of Neotropical Annonaceae. Candollea 49: 389-481.

Maas, P.J.M., E.C.H. van Heusden, J. Koek-Noorman, A.K. van Setten \& L.Y.Th. Westra. 1988. Studies in Annonaceae IX. New species from the Neotropics and miscellaneous notes. Proc. Kon. Ned. Akad. Wetensch., Ser. C 91: 243-282.

Maguire, B., J.J. Wurdack \& Collaborators. 1957. The botany of the Guayana highland - part II. Mem. New York Bot. Gard. 9: 235-392.

Maguire, B., J.J. Wurdack \& Collaborators. 1960. The botany of the Guayana highland - part IV. Mem. New York Bot. Gard. 10: 22-23.

Presl, K.B. 1835. Reliq. Haenk. 2: 78.

Ruiz López, H. \& J.A. Pavón. 1794. Florae peruvianae, et chilensis prodromus. Imprenta de Sancha, Madrid.

Ruiz López, H. \& J.A. Pavón. 1798. Systema vegetabilium florae peruvianae et chilensis. Gabrielis de Sancha, Madrid.

Scharf, U., P.J.M. Maas \& W. Morawetz. 2005. Five new species of Guatteria (Annonaceae) from the Pakaraima mountains. Blumea 50: 563-573.

Scharf, U., P.J.M. Maas \& W. Morawetz. 2006a. Five new species of Guatteria (Annonaceae) from French Guiana, Guyana and Suriname. Blumea 51: 117-130.

Scharf, U., P.J.M. Maas \& W. Morawetz. 2006b. Guatteria richardii (Annonaceae) rediscovered along with two new species from French Guiana. Blumea 51: 541-552.

Scharf, U., P.J.M. Maas \& M.F. Prévost. 2008. An unusual new species of Guatteria (Annonaceae) from French Guiana and adjacent Brazil (Amapá). Blumea 53: 515-523.

Simpson, D.R. 1975. New species from South America II. Phytologia 30: 305-310.

Stearn, W.T. 1938. Presl's 'Reliquiae Haenkeanae'. J. Soc. Bibliogr. Nat. Hist. 1: 153-154.

Triana, J.J. \& J.É. Planchon. 1862. Prodromus florae novo-granatensis. Ann. Sci. Nat., Bot. sér. 4, 17: $25-40$.

Van Setten, A.K. \& J. Koek-Noorman. 1992. Studies in Annonaceae XVII. Fruits and seeds of Annonaceae: morphology and its significance for classification. Biblioth. Bot. 142: 1-101.

Van Setten, A.K. \& P.J.M. Maas. 1990. Studies in Annonaceae XIV. Index to generic names of Annonaceae. Taxon 39: 675-690.

Vásquez, R. 1997. Flórula de las Reservas Biológicas de Iquitos, Perú, Allpahuayo-Mishana, Explornapo Camp, Explorama Lodge. Monogr. Syst. Bot. Missouri Bot. Gard. 63: 1-1046.

Von Martius, C.F.P. 1841. Flora brasiliensis 13, 1: 1-64; pl. 1-14. Frid. Fleischer in comm., Munchen, Leipzig.

Von Schlechtendahl, D.F.L. 1834. De Annonaceis Brasiliensibus Herbarii Regii Berolinensis. Linnaea 9: $315-331$.

\section{IDENTIFICATION LIST}

The abbreviations behind the collector numbers refer to the following names: For G. asplundiana: aberrant material (as explained in the species description is bold).

$\begin{array}{llll}\text { are }=\text { G. } \text { arenicola } & \text { duo }=\text { G. duodecima } & \text { jap }=\text { G. japurensis } \\ \text { arg }=\text { G. argentea } & \text { flb }=\text { G. flabellata } & \text { meg }=\text { G. megalophylla } \\ \text { asp }=\text { G. asplundiana } & \text { flg }=\text { G. flagelliflora } & \text { mic }=\text { G. microcarpa } \\ \text { bre }=\text { G. brevipetiolata } & \text { fra }=\text { G. fractiflexa } & \text { pas }=\text { G. pastazae } \\ \text { con }=\text { G. confusa } & \text { gen }=\text { G. gentryi } & \text { sca }=\text { G. scalarinervia } \\ \text { dis }=\text { G. discolor } & \text { gra }=\text { G. grandipes } & \text { ven }=\text { G. venosa }\end{array}$


Acevedo-R. \& Cedeño 7355: sca - Aguinda et al. 1416: asp - Alvarez et al. 809: mic; 1788, 1900, 1981: asp - Amaral et al. 241: flb; 518: jap - Ancuash 469: pas - Arévalo et al. 66: flb - Asplund 18833, 19673: asp - Aulestia et al. 693, 1187, 1358: ven; 2472, 2595, 2663: sca.

Baker et al. 5716: pas - Bétancur et al. 854: meg; 887: asp - Bloch \& Valencia 67916: sca - Bonifaz \& Cornejo 3726, 3748, 3756, 3832: ven - Brant et al. 1474, 1752: asp.

Callejas et al. 4230, 5535, 8306, 8542: asp - Campbell et al. 8817: duo - Campos et al. 3414, 3557: pas; 3786, 3881, 5529, 6520: asp - Cerón et al. 7533, 9096: gen; 19940, 20160: mic - Chatrou et al. 22, 25: duo; 174: sca; 441, 442, 463: duo - Christenhusz \& Cárdenas-Ramires 2110: fra - Cid et al. 7280, 7421: flb; 10699: are - Cogollo et al. 1533, 2519, 3277, 3990, 4188, 6528, 7417, 7641, 7582: asp - Cornejo et al. 26: duo; 3368, 4869, 5178: mic - Croat 19183: flb.

Daly et al. 4472: flb - Davidson \& Revilla 5446: flb — Díaz et al. 1478: con; 6991, 7162, 7237 : asp; 7888: pas; 7991, 8010, 10158: asp; 10260: pas; 10819: asp - Dik 705: sca — Dodson et al. 14807: ven; 15049: asp

Eggers 14376: mic - Encarnación 960: flb.

Faber-Langendoen \& Hurtado 1743: arg - Fonnegra et al. 3135, 3140, 6351: asp — Freire et al. 165, 178: gen; 467: asp; 707: sca.

Gentry et al. 12435, 12444: gen; 14429: mic; 20364: flb; 20430: sca; 22860, 22870: asp; 24882, 27686: flb; 39607: sca; 37773: are; 45155, 45732, 45841: duo; 46221, 51123: dis; 57667: duo; 70116: ven; 77361: sca; 78417: duo; 78908, 78956: asp; 80233, 80686: duo - Grández et al. 1683, 2593: flb; 2788: gra; 2942,11882: flb - Gudiño 307: gen - Guevara \& Guaman 503: gen.

Harling \& Andersson 23337: ven; 24410: asp - Haxaire 2984: duo - Holm-Nielsen et al. 2606: mic - Homeier et al. 1570: pas; 1897: asp; 2078, 2098: pas; 2261: asp; 2338, 2459: gen; 3400, 3497, 3644: asp; 3707: gen; 3819: pas - Hoyos \& Hernández 276, 592, 765, 793, 840, 930, 1045: asp - Hurtado et al. 145, 1002: asp.

Jaramillo, J.L. 5: asp - Jaramillo, N. et al. 464: asp; 1201, 1269: pas - Játiva \& Epling 832: mic. Kajekai et al. 50, 59: pas - Korning \& Thomsen 47656: duo - Krukoff 11095: duo.

Lewis et al. 3445: mic - Lowrie et al. 23: flb - Lugo S. 181, 227: pas; 5140, 5169: gen.

Maas et al. 1183: dis; 6297: flb; 6504, 6505: mic; 8269: sca; 8593: duo; 8980: are - MacDougal et al. 4107: meg; 4156: asp - McPherson et al. 12992, 13264: asp - Méndez et al. 284: ven - Monsalve B. 182, 502, 511, 706, 1262: arg - Monteagudo et al. 5757: duo - Morales \& Reyes 1815: asp; 1885: pas - Mori et al. 9125: flb.

Naranjo \& Freire 180, 370, 474: sca - Nee 31691: duo - Neill et al. 5805, 6009: pas; 7326: duo; 7954: sca; 8106: duo; 8858, 8900: gen; 9452: duo; 13159: asp; 14269: pas; 15010: asp — Nicolalde et al. 1200, 1374: asp - Nuñez et al. 11448: duo.

Øllgaard et al. 57186: duo.

Palacios 7075: gen — Palacios et al. 1120: sca; 1643, 2596, 2648: mic; 4097, 4104, 4614: asp; 4654: duo; 5205: mic; 5502: asp; 5539, 5617: gen; 5973, 6039: asp; 7075: gen; 8474: pas; 12213 : ven - Pennington, R.T. et al. 124: duo - Pennington, T.D. et al. 14941: bre; 15384, 15607: ven - Perea et al. 259: duo - Pipoly et al. 17863, 18330: asp - Pirie et al. 122: asp; 131, 138: pas; 157, 158, 166: are; 172: pas - Pitman 1307: mic; 6104: sca - Prance et al. 6819: flb; 8550: meg.

Quizhpe et al. 594: asp; 1171: pas?

Ramírez 4461: asp - Renner 69066: sca - Revilla et al. 1819: flb; 2099: dis; 2188: sca; 3349: flb - Reyes \& Morales 1172: pas - Rimachi Y: 6713: flb; 10079: are - Rodriguez R. \& Cruz A. 2053: pas? - Rodriguez et al. 578: gen; 2740: fra - Rojas et al. 393, 472: asp - Romoleroux et al. 1966, 2184, 2317, 2933: sca - Ronquillo et al. 922: asp - Ruiz, J.C. et al. 1078, 1134: flb.

Sánchez et al. 896, 997: asp - Sánchez-Vega et al. 9908: are — Smith 5290: duo — Ståhl \& Cornejo 6166 : mic - Stein et al. 4002: gra.

Thomas \& Agustin 2024: duo - Tipaz et al. 1119, 1336: ven.

Van der Werff et al. 12046: ven; 16333: fra; 19221: pas - Vargas et al. 683, 920, 927: gen; 1249, 5685, 5757: mic - Vásquez et al. 2348: sca; 3629, 4461: flb; 5636: sca; 7352, 7466, 7489, 7998, 8387: flb; 8422: con; 8589, 9434, 9484, 9690, 13060, 13280: flb; 13319: duo; 17520: con; 20391: gen; 20442: asp; 22500: flg; 24433: gen; 24650: fra; 24672, 26150, 27362: asp; 27596: fra.

Zak \& Espinoza 4811, 5016, 5057: duo - Zaruma 553: sca. 